University of Louisville

ThinkIR: The University of Louisville's Institutional Repository

\title{
"The only true American republic" : Vermont independence and the development of constitutional government in the early United States.
}

Jacob Michael Abrahamson

University of Louisville

Follow this and additional works at: https://ir.library.louisville.edu/honors

Part of the United States History Commons

\section{Recommended Citation}

Abrahamson, Jacob Michael, "'The only true American republic" : Vermont independence and the development of constitutional government in the early United States." (2017). College of Arts \& Sciences Senior Honors Theses. Paper 145.

http://doi.org/10.18297/honors/145

This Senior Honors Thesis is brought to you for free and open access by the College of Arts \& Sciences at ThinkIR: The University of Louisville's Institutional Repository. It has been accepted for inclusion in College of Arts \& Sciences Senior Honors Theses by an authorized administrator of ThinkIR: The University of Louisville's Institutional Repository. This title appears here courtesy of the author, who has retained all other copyrights. For more information, please contact thinkir@louisville.edu. 
"The Only True American Republic":

Vermont Independence and the

Development of Constitutional Government

in the Early United States

By

Jacob Michael Abrahamson

Submitted in partial fulfillment of the requirements

for Graduation summa cum laude

University of Louisville

March 27, 2017 
"Nothing is more distressing to those who have a due respect for the constitutional modifications of power than to be obliged to decide on them."

- James Madison, Virginia Delegate, January 22, 1782 
"The Only True American Republic": Vermont Independence and the Development of Constitutional Government in the Early United States

\section{Introduction}

Institutions of constitutional government in the United States were not created within a vacuum; rather, these institutions resulted from a complicated historical context. Unanticipated and unprecedented circumstances filled the era of the American Revolution and Confederation. The individuals responsible for making decisions during this era faced the task of establishing the fundamental bases of a new nation. In doing so, they based their decisions upon both the zeitgeist of Whig political ideology that permeated the period and the exigencies of fighting a war and building a nation, all at once. The tension between the idealistic and the pragmatic outcome defined the decision-making process. The controversy over Vermont which took place in the Continental Congress from 1778 to 1789 created this tension. According to Peter S. Onuf, "jurisdictional confusion created a mandate for a stronger central government."1 Before a stronger central government could be formed, delegates would be forced to handle the Vermont controversy.

From 1750 until Vermont entered the Union in 1791, New York, New Hampshire, and the self-proclaimed Vermonters struggled for jurisdiction over the territory and whether the right to form a sovereign state through revolution existed. ${ }^{2}$ In 1778 New Hampshire delegate William Whipple wrote that he was "much inclined to think the western part of the State will be kept in a

${ }^{1}$ Peter S. Onuf, The Origins of the Federal Republic: Jurisdictional Controversies in the United States, 1775-1787 (Philadelphia, PA: University of Pennsylvania Press, 1983), 3.

2 The term Vermont is used to describe the disputed territory between New York and New Hampshire. At different times, it was known to contemporary audiences as the New Hampshire Grants, New Connecticut, and Vermont. It is here called Vermont for the sake of consistency. 
perpetual Broil "till a final settlement of the Jurisdiction."3 Over time, Whipple's prediction proved correct. The Vermont controversy proved to delegates in Congress how weak and divisive the Articles of Confederation could be. Vermont as a case study also shows that delegates to Congress had an unclear view of their own institutional power. Ultimately, they would be forced to define the limits of their own power to define states. This struggle to understand the power of their own institution proved critical to the development and function of the federalist institutions created by the 1787 United States Constitution.

This paper analyzes the debates over the Vermont controversy in the Continental Congress which illuminate a broader debate about congressional power and the key problems of American federalism. Through a study of secondary source material on the development of the American republic, an analysis of the internal politics of New York and Vermont as the controversy developed, and an analysis of the letters to and from delegates to Congress, this paper argues that the Continental Congress questioned its own ability to take any decisive action. That realization, in turn, led to a failure to resolve the issue until after the ratification of the 1787 Constitution. In its conclusion, this paper analyzes how the Vermont issue affected the broader debate over the nature and limits of American federalism and the channels and limits of congressional power.

\section{Literature Review}

${ }^{3}$ William Whipple to Meshech Weare, December 4, 1778, in Paul Smith, et. al., eds. Letters of Delegates to Congress, 25 vols. (Washington, D.C.: Library of Congress, 1976-2000), 11: 339. Any spelling or grammatical errors found within these letters were left intact, so as to maintain them as written when quoted. Some editor's markings were removed to improve readability. Hereafter, letters from this collection will be cited as $L D C$. 
Much like the Revolutionary and Founding eras, histories began to be written about the issue of Vermont independence before the dust of revolution had settled. While publications exist from the nineteenth century — and they carried value as guides for later historians - those works do not stand out among more modern sources. The most frequently cited monograph on the Vermont question was Chilton Williamson's 1949 Vermont in Quandary: 1763-1825.4 Inward-looking, this work focused more on the motives of land speculators in Vermont and the many forces that worked to create the conflict over land in Vermont. Although it did not focus on the Continental Congress, later works treated Williamson's work as an authority on the details of the conflict and especially so on the motives of Vermont's leaders. While they made a valuable contribution to the study of this issue, historians such as Williamson's work, Hilland Hall's 1868 The History of Vermont From Its Discovery to Its Admission Into the Union in 1791, ${ }^{5}$ Matt B. Jones's 1939 Vermont in the Making: 1750-1777, ${ }^{6}$ told the story from a local viewpoint. To date, only a few historians have produced scholarship on the Vermont issue from an outside perspective.

In his 1955 University of Michigan dissertation “The Vermont Problem in the Continental Congress and in Interstate Relations, 1776-1787," 7 Winn L. Taplin, Jr. offered one of the first non-Vermont-based viewpoints on the Vermont issues. ${ }^{8}$ Vermont authors constituted his main

${ }^{4}$ Chilton Williamson, Vermont in Quandary: 1763-1825 (Montpelier, VT: Vermont Historical Society, 1949).

${ }^{5}$ Hilland Hall, The History of Vermont, From Its Discovery to Its Admission Into the Union in 1791 (Albany, NY: J. Munsell, 1868).

${ }^{6}$ Matt Bushnell Jones, Vermont in the Making: 1750-1777 (Cambridge, MA: Harvard University Press, 1939).

${ }^{7}$ Winn L. Taplin, Jr., "The Vermont Problem in the Continental Congress and in Interstate Relations, 1776-1787” (PhD dissertation, University of Michigan, 1955).

8 Ibid., 1. In his first paragraph, Taplin acknowledged that he is the first non-local historian. 
secondary sources, but he made use of state archives and primary source material, including Edmund Burnett's original 1921 Letters of Members of the Continental Congress, ${ }^{9}$ in order to develop his argument. Perhaps Taplin's most important contribution was his handling of the complicated power struggle that occurred within Vermont. Taplin's study explained why the issue cannot be viewed as a simple conflict between New York and the Vermont settlers. Because land speculation lay at the root of the original conflict, Taplin acknowledged the tensions between New York, New Hampshire, Massachusetts, Vermont, and the College Party, a group that sought unity in the Connecticut River Valley. ${ }^{10}$ Within these groups, a large cast of characters - ranging from Founding Fathers to lesser-known Vermonters - dealt with the issue directly. Despite a sometimes shaky and repetitive chronology, Taplin handled an often overwhelming amount of actors and historical development within his dissertation, and his work served as an excellent guide to the order in which the issues developed.

Taplin's main argument— that the handling of the Vermont issue made Congress's weaknesses evident—was important and another key to the usefulness of his work. He stated that the issue was "never solved by the Continental Congress" because "the revolt within a revolt was too much for its sketchy powers and internal jealousies." 11 While weak national government was a common and often over-emphasized theme in the nationalist-focused historiography of the era which highlighted the 1789 Constitution and treated the Articles of Confederation as a total failure, Taplin used the Vermont issue as an effective argument for an

${ }^{9}$ Edmund Burnett, ed. Letters of Members of the Continental Congress, 8 vols. (Washington, D.C.: Library of Congress, 1921). This is the predecessor to the Letters of Delegates to the Continental Congress, cited in the present study.

${ }^{10}$ Taplin, 2.

${ }^{11}$ Ibid., 2-3. 
issue on which the government was ineffective. Taplin's argument about Congress's "inability to resolve vital issues"12 presented an important conclusion to be drawn from the Vermont issue.

The most notable recent historical work regarding the Vermont issue is Onuf's 1983 The Origins of the Federal Republic: Jurisdictional Controversies in the United States, 1775-1787.13 The Vermont issue was only one of many topics within the monograph, and in his introduction Onuf wrote of the underlying question in all of the jurisdictional disputes he discussed: "how to reconcile state and congressional authority and ... how to provide for the interests of the states collectively and of the American people in general." 14 Onuf cited jurisdictional disputes as a definitive aspect of early American constitutional history and pointed to the power struggle as the key motivator of state interaction and government behavior. ${ }^{15}$ Origins of the Federal Republic had different utility than Taplin's work due to the context in which it was created. Because his work was published in 1983, 28 years after Taplin's dissertation, Onuf's work was a product of the major historiographical shift in the historiography of the American Revolution that had taken place in the time since Taplin's work. ${ }^{16}$

In the chapter on the Vermont issue, Onuf agreed with Taplin's assessment of Congress's weakness. Stating that "Vermont's survival as a state was made possible by the inability of the claiming states to enforce their jurisdictional claims, ${ }^{17}$ he confirmed the lack of enforcement power held in Congress. However, Onuf went one step further than Taplin in discussing the

\footnotetext{
12 Ibid., 371.

13 Onuf, The Origins of the Federal Republic.

${ }^{14}$ Ibid., Xv.

15 Ibid., 3.

16 This historiographical shift will be discussed in depth below.

17 Ibid., 144.
} 
tension between New York's legal claim over Vermont and the revolutionary feeling of the age. This analysis pointed to the irony of congressional leaders - revolutionaries themselves — being asked to adjudicate between Vermont's revolutionaries and New York territorial interests. Onuf called Vermont "the only true American republic, for it alone had truly created itself."18 The actions of Congress which New York desired, Onuf wrote, "sanctioned the exercise of state authority with the same supposedly arbitrary rationale that the British invoked against the states themselves."19 Onuf's arguments were bold, and his work proved key to understanding the Vermont issue in a broader context.

While historical writing with a specific Vermont focus is limited, historians have spilled enormous amounts of ink analyzing late-eighteenth century American politics. Because the Vermont issues spanned from 1750 to 1791, all aspects of the Founding-independence, the Articles of Confederation, and the Constitutional Convention-required coverage. In 1958, the same year that Taplin wrote his dissertation, Forrest McDonald published We the People: The Economic Origins of the Constitution, ${ }^{20}$ a direct rebuttal to Charles Beard's 1913 An Economic Interpretation of the Constitution of the United States. ${ }^{21}$ Widely accepted until 1958, Beard credited economic interests as the motivating force behind the Founders; however, McDonald used archival research to discredit Beard's thesis. More significant to the present study was the historiographical shift caused by McDonald's work. The way in which historians studied the

\footnotetext{
18 Ibid., 145.

19 Ibid., 131.

${ }^{20}$ Forrest McDonald, We the People: The Economic Origins of the Constitution (Chicago, IL: University of Chicago Press, 1958).

${ }^{21}$ Beard, An Economic Interpretation of the Constitution of the United States (New York: The Macmillan Company, 1913).
} 
Founding era underwent significant change in the mid-twentieth century; thus, most early works related to the Vermont issue lacked some depth because they were published before works like McDonald's caused an historiographical shift.

The most relevant of McDonald's work to the Vermont issue was the 1965 E Pluribus Unum: The Formation of the American Republic 1776-1790. ${ }^{22}$ In this monograph, McDonald turned the motto- "E Pluribus Unum"—on its head by beginning with a chapter entitled "From One, Many." Crucial to the understanding of interstate relations in Congress in the Vermont issue, his argument centered around the sometimes sour relationships between states. As he put the problem, "the first enemy of the Republic to appear [on the political front]. . was state jealousy."23 While McDonald's support for the compact theory of the Union lay out of the mainstream and was qualified by later works, his understanding of the behavior and interaction of state governments was indispensable. McDonald depicted New York as one of the strongest early states under confident executive leadership, ${ }^{24}$ which played a role during the height of the Vermont issue and confirmed McDonald's view that "different colonies had supported the revolution in support of different goals. ${ }^{, 25}$ His work allowed each state's history and interests to be brought into the broader analysis of power under the Articles of Confederation. In later years, McDonald authored Novus Ordo Seclorum: The Intellectual Origins of the Constitution (1985), ${ }^{26}$

${ }^{22}$ Forrest McDonald, E Pluribus Unum: The Formation of the American Republic 1776-1790 (Indianapolis, IN: Liberty Press, 1979).

${ }^{23}$ Ibid., 36.

${ }^{24}$ Ibid., 109-116.

${ }^{25}$ Ibid., 40.

${ }^{26}$ Forrest McDonald, Novus Ordo Seclorum: The Intellectual Origins of the Constitution (Lawrence, KS: University Press of Kansas, 1985). 
a successor to another genre of history developed in the 1960 s which also had an important impact on the study of the Vermont issue and the Founding era: ideological history.

The school of thought modern historians such as Onuf had the benefit of working from was the ideological or "republican consensus" history found most notably in Bernard Bailyn's 1967 Ideological Origins of the American Revolution. ${ }^{27}$ With this starting point, historians began to interpret the underlying ideas and values of American political leaders in the late eighteenth century. While McDonald's influence loomed large on the study of the Founding era, by comparison Bailyn's has had a much stronger ripple effect across historical scholarship. The product of an edited collection of revolutionary pamphlets, in Ideological Origins Bailyn found new evidence to prove his argument that ideas mattered. Following his professor's footsteps, Gordon S. Wood published his own 1969 volume, Creation of the American Republic 1776-1787, ${ }^{28}$ which folded into an argument similar to Bailyn's, with more emphasis on extending opposition political theory.

In this work, and his 1992 work The Radicalism of the American Revolution, ${ }^{29}$ Wood further developed an understanding of the ideological origins of the Founding Era. While Bailyn concerned himself with the lead-up to the American Revolution, Wood sought to understand the workings of a developing national government after the Revolution had concluded. This task led to a discussion of state constitutions which was further analyzed in Pauline Maier's 1997

\footnotetext{
27 Bernard Bailyn, The Ideological Origins of the American Revolution (Cambridge, MA: Harvard University Press, 1967).

${ }^{28}$ Gordon S.Wood, The Creation of the American Republic: 1776-1789, (Chapel Hill, NC: University of North Carolina Press, 1969).

29 Gordon S. Wood, The Radicalism of the American Revolution (New York: Alfred A. Knopf, 1992).
} 
American Scripture: Making the Declaration of Independence,$^{30}$ discussed below. Wood focused on the development of Vermont's constitution in conjunction with the writing of other state constitutions. ${ }^{31}$ In many ways, reading Wood's descriptions of the national leaders of the American Revolution as cautious and thoughtful figures - outside the typical mold of revolutionaries - is similar to discussing the revolutionaries who led the Vermont independence movement. ${ }^{32}$ This similarity is unsurprising as Vermonters also believed in the revolutionary and Whig ideas analyzed and described by Bailyn and Wood. Wood's works suggested that Vermont, while not officially a part of the new nation, developed as a part of a national movement towards the creation of a national, republican government influenced by eighteenth-century Whig ideas. Maier also dealt with ideological history in her American Scripture, although the study concerned itself primarily with the road to creating the Declaration of Independence. The monograph delved into the committee drafting process in addition to an interesting discussion of local declarations of independence which preceded the national declaration. Maier also analyzed the role of the Second Continental Congress in the work of the nation including "the task of resolving internal disputes ... of the settlers of Vermont with New York." ${ }^{33}$ At the time, it was far less clear-cut whether interstate conflict resolution was found within the powers of the Continental Congress. She pointed out, however, that the issue remained in play. Key to understanding the lead-up to independence, her work lent itself to the underlying themes in the study of the Vermont issue. However, she also discussed the Vermont issue specifically, tying

\footnotetext{
${ }^{30}$ Pauline Maier, American Scripture, Making the Declaration of Independence (New York: Vintage Books, 1997).

31 Wood, Creation of the American Republic, 161-63.

32 Wood, Radicalism, 3.

33 Maier, American Scripture, 13-14.
} 
Vermont's Declaration of Independence to the model Pennsylvania set ${ }^{34}$ and relating Vermont's effort to create its own Constitution with the congressional Declaration of Independence. ${ }^{35}$ Yet, besides the obvious influence over individuals and the structures of government they created, why were the ideological origins important to the Vermont issue? Because, as Onuf stated, Vermonters were no less affected by the Whig ideas flowing through the new nation. While personal and property-based interests were an important cause of the conflict, the settlers in Vermont who declared independence also believed in independence from arbitrary rule and popular sovereignty located in "the people." In their own view, Vermonters sought freedom as Congress struggled to reconcile with the consequences of independence.

Understanding the Continental Congress as an institution is essential to an analysis of their handling of the Vermont issue. The earliest secondary literature on this subject is Edmund C. Burnett's 1941 The Continental Congress, ${ }^{36}$ still a foundational text for a historian of this era. Burnett is the same historian who published the original collection of letters of delegates to the Continental Congress, and his work is still used and respected by modern historians. Burnett argued that the structures developed within the Continental Congress were integral to the creation of the United States of America. The monograph tracks a positive growth of those structures. While this work is a broad overview, Burnett also treated the Vermont question as a setback in this development adding that the region was "vexatious enough even in the earlier stages of fermentation and destined to torment the Continental Congress from time to time until

\footnotetext{
34 Ibid., 166-67.

35 Ibid., 275, see footnote 22.

36 Edmund C. Burnett, The Continental Congress (New York: The Macmillan Company, 1941).
} 
its last hours." ${ }^{\prime 37}$ This summary captured the relationship between Congress and Vermont to be studied in the present work. Burnett's work and any other study that relied upon the first-hand accounts or correspondence of members of Congress, may be supplemented by Mary Sarah Bilder's 2015 Madison's Hand: Revising the Constitutional Convention. ${ }^{38}$ This monograph was unrelated to the Vermont question, as it focused on the Constitutional Convention notes; but, Section I, "Notes Before the Constitutional Convention," was useful to understanding how the key figures of the era recorded the events in Congress. Bilder's work shed light on the composition of many of the primary sources used by Burnett and other historians of the era.

The 1783 Articles of Confederation, provided the framework for how Congress acted in this period. One of the few monographs related to the Articles is Merrill Jensen's 1940 The Articles of Confederation: An Interpretation of the Social-Constitutional History of the American Revolution 1774-1781.39 Despite his tendency toward Beard's school of thought, even McDonald treated Jensen's work as the standard on the Articles of Confederation, likely due to their agreement on the compact theory of union. With a clear preference for the government under the Articles, Jensen called the Articles the "embodiment in form of the philosophy of the Declaration of Independence," 40 making the assumption that the two documents settled the ideological issues of the day. Jensen furthered these views in his 1950 The New Nation: A

${ }^{37}$ Ibid., 239.

38 Mary Sarah Bilder, Madison's Hand: Revising the Constitutional Convention (Cambridge, MA: Harvard University Press, 2015).

${ }^{39}$ Merrill Jensen, The Articles of Confederation: An Interpretation of the Social-Constitutional History of the American Revolution 1774-1781 (Madison, WI: University of Wisconsin Press, 1940).

40 Ibid., 15. 
History of the United States During the Confederation, 1781-1789..11 Focused on the main ten years of what some call "the critical period," Jensen described a nation at the end of the revolutionary war suddenly tasked with true self-governance. "As the war ground to an end," Jensen wrote, "American political leaders tried to solve what seemed to be insoluble problems. ${ }^{" 42}$ On the Vermont question, the monograph brushed over and oversimplified the issue, saying the dispute was "solved" by the creation of an independent state. ${ }^{43}$ However, much like his original work, The New Nation covered important issues and power struggles between national and state interests. These issues proved critical to both the Constitutional Convention and to understanding how the Vermont question was handled.

Jack P. Greene, in the 1982 "The Background of the Articles of Confederation," 44 rejected Jensen's view of the Articles of Confederation and instead pointed to a nationalist theory. According to Greene, the compact theory made the line between state sovereignty and congressional power too clear cut when the distribution of power instead required analysis of the subtle meanings and actions behind the written documents. ${ }^{45}$ The debate over compact theory remained fierce, as even recent historians such as Derek H. Davis argued in 2000 that "the notion that the sovereignty of the Continental Congress was superior to that of the colonies/states, as some have sought to do, is indeed a misreading if not a revisionism of the worst kind." ${ }^{46}$ These

${ }^{41}$ Jensen, The New Nation: A History of the United States During the Confederation, 1781-1789 (New York: Alfred A. Knopf, 1950).

42 Ibid., 4.

${ }^{43}$ Ibid., 337. As more detailed secondary sources indicate, the creation of an independent republic further complicated the Vermont dispute and did not solve it. ${ }^{44}$ Jack P. Greene, "The Background of the Articles of Confederation," Publius 12, (1982): 15-44. ${ }^{45}$ Ibid., 41.

${ }^{46}$ Derek H. Davis, Religion and the Continental Congress, 1774-1789: Contributions to Original Intent (Oxford: Oxford University Press, 2000), 118. 
words were harsh and misguided, as Greene and other historians were the most-respected authors on this subject in recent years and their school of thought dominated the debate. However, Davis leveled a fair criticism of the nationalist school as the proper answer lay somewhere in the middle. A more recent historian, Aaron N. Coleman, also criticized the nationalist view in his 2016 monograph, The American Revolution, State Sovereignty, and the American Constitutional Settlement, 1765-1800.47 While he accepted some of Greene and McDonald's arguments, he wrote that the Founders established "state sovereignty as the bedrock of their constitutional order." ${ }^{48}$ While Coleman may be correct in that modern historians overlook state sovereignty, he overstated their importance to the Founders. The challenges of the 1780s which precipitated the Constitutional Convention and developed a nation make Jack N. Rakove's arguments a more convincing view of the period.

In the key monograph on state and national power under the Continental Congress, Rakove, in The Beginnings of National Politics: An Interpretive History of the Continental Congress (1979), ${ }^{49}$ adopted a nationalist view but was moderate compared to Greene. Rakove was perhaps most clear in explaining why no defined scope of congressional authority existed. As the Vermont episode showed, Congress was in the process of experimenting and discovering what its role was in the new American system. That experimentation, in many ways, was the value of the Confederation period: realizing the demands of what James Madison described as an

${ }^{47}$ Aaron N. Coleman, The American Revolution, State Sovereignty, and the American Constitutional Settlement, 1765-1800 (Lanham, MD: Lexington Books, 2016).

${ }^{48}$ Ibid., 1-10.

${ }^{49}$ Jack N. Rakove, The Beginnings of National Politics: An Interpretive History of the Continental Congress (New York: Alfred A. Knopf, 1979). 
"extended republic." ${ }^{50}$ According to Rakove, most delegates "probably rejected ... the inherent sweep of congressional authority without giving up an intuitive belief that in certain critical cases Congress must reign supreme." ${ }^{51}$ Rakove's arguments were valuable to understanding the era of the Articles of Confederation, a critical time for Vermont's efforts for statehood. The day-to-day politics of the Confederation Congress, which he sought to understand, proved key in the Vermont issue.

Rakove also authored the 1996 Original Meanings: Politics and Ideas in the Making of the Constitution, ${ }^{52}$ for which he won the Pulitzer Prize. Rakove sought to understand the creation of the national government as part of a political and legal theory, similar to the earlier Beginnings of National Politics. Especially interesting is the chapter on federalism, which acknowledged that "the existence of the states was simply a given fact of American governance, and it confronted the framers at every stage of their deliberations." ${ }^{53}$ Although it did not exist in an official capacity, Vermont was perhaps one of the most complicated state-related issues that existed at the time of the framing. The unsolvable Vermont question bothered members of Congress throughout their tenure and was on their mind when considering what kind of federal system should exist. Rakove cited the Vermont question as one of the remaining controversies at the time of the framing of the Constitution. As with many secondary sources described above,

${ }^{50}$ James Madison, Federalist 10 in The Federalist Papers, ed. George W. Carey and James McLellan (Indianapolis, IN: Liberty Fund, Inc, 2001), 42-49.

${ }^{51}$ Rakove, Beginnings of National Politics, 184. Coleman explicitly rejected Rakove's argument that sovereignty was not always a primary concern (Coleman, 4).

52 Jack N. Rakove, Original Meanings: Politics and Ideas in the Making of the Constitution (New York: Alfred A. Knopf, 1996).

${ }^{53}$ Rakove, Original Meanings, 162. 
this work lent perspective on how the framers thought about the largest issues of the era exemplified by the Vermont question.

The bulk of existing literature related to the Vermont issue is related to the Founding era in a general sense. Whether discussing interstate relationships, ideological foundations, or the mechanics of the politics of the various forms of governments of the era, these historical works lent themselves to any discussion of the Vermont issue. While the body of work dealing with the Vermont issues is small, historians such as Taplin and Onuf offer detailed, helpful information and arguments regarding the issue. With these two existing bodies of literature, the foundation for a case study in the development of American federalism may be built. However, any attempt to tie together the development of federalism and the resolutions of tensions in the Vermont issue must be made through textual analysis of primary source material.

\section{Early Context \& Key Figures}

While the Vermont controversy in the Continental Congress constitutes the focus of the present study, it is but one aspect of the Vermont controversy. Its relationship to the establishment of a national legislature in the United States may be drawn from the interactions which took place within the Continental and Confederation Congresses; however, key events which shaped the question in Congress took place long before the delegates in Philadelphia took up the question. In addition, key figures emerged throughout the colonies and in Vermont who played a role in the controversy throughout its discussion within Congress. The context of the controversy before it reached Congress - from the the original New Hampshire Grants in 1750 to Vermont's declaration of independence in 1777-is crucial to a full understanding of the issue as 
it was placed before Congress. This context includes the early development of the controversy and the individuals responsible for its precipitation.

As early as 1750 , a conflict over disputed territory that would become Vermont arose between New York and New Hampshire. In that year, New Hampshire's royal governor Benning Wentworth began to challenge the boundaries between New York and New Hampshire. According to Taplin, in 1749 "Wentworth had written with a show of innocence to New York's governor, George Clinton, to inquire how far New York extended to the east of the Hudson River."54 Despite receiving a clear answer from Clinton that the Connecticut River was the boundary, ${ }^{55}$ Wentworth created fifteen towns west of the river, with the town of Bennington as close as 20 miles east of the Hudson River. ${ }^{56}$ Wentworth awarded grants to 112 more towns by 1764, ignoring an agreement with New York to wait for a final resolution from England. ${ }^{57}$ With these actions taken, as Taplin noted, "trouble was inevitable." 58 Out of the early stages of this developing conflict arose a few key figures and interest groups.

From 1750 and throughout the early stages of the controversy, Wentworth was not only the main instigator of the illegal land grants, but a benefactor from it. Although he knew a royal decision was forthcoming, Wentworth persisted in making grants across the Connecticut River. According to Edward P. Alexander's 1966 A Revolutionary Conservative: James Duane of New York, "Wentworth could well afford to take a chance on the royal decision, because he received

54 This George Clinton, although distantly related to the better-known American politician, was an older provincial governor. The younger George Clinton would not be elected governor until 1777.

${ }^{55}$ See Appendix II for a map of the disputed territory.

56 Taplin, 1-2.

${ }^{57}$ Ibid., 3.

58 Ibid., 8. 
two rights in each grant and his relatives and close friends were patentees."59 To bolster the grants, Wentworth made the argument that New Hampshire stretched as far west as Massachusetts. However, there was no legal basis for this argument and was based solely on his own interests, as he himself held approximately 65,000 acres of land in the New Hampshire Grant regions. ${ }^{60}$ Wentworth's early attitude toward the region set a precedent for constant disagreement with the New York position, no matter the legal argument. This self-interested behavior laid the groundwork for the future development toward Vermont independence.

In 1764, the British Privy Council reached what they thought was a final decision. In that decision, the Privy Council determined the boundary of New York "to be" the Connecticut River. ${ }^{61}$ After the decision of the Privy Council, land speculation and fees became a constant underlying issue for all parties to the controversy, and while land speculation and fees fell out of focus in the later debates, they formed a key part of the context of the controversy. The futuretense language of the Privy Council ruling served to make the conflict worse. Williamson accurately summarized the disagreement which surrounded the decision: "If this decision had declared merely that the Grants were transferred from the jurisdiction of New Hampshire to that of New York, the speculators in New Hampshire titles would have had little to fear. But, unhappily for them, the wording of the decision provided New York with the opportunity to state that the lands in dispute had been under the jurisdiction of New York since 1664 and, hence, titles derived from New Hampshire were illegal." 62 New Hampshire settlers did have some stake

${ }^{59}$ Edward P. Alexander, A Revolutionary Conservative: James Duane of New York (New York: AMS Press, Inc., 1966), 69.

60 Taplin, 4-6.

${ }^{61}$ Ibid., 1.

62 Williamson, 11. 
in this land, as they had already developed some of it and paid fees to New Hampshire; thus, the fees associated with New York's jurisdiction was one of their main concerns. New York permitted original title-holders to maintain their lands, but they were unsatisfied with the high fees and did not take advantage of the offer until 1772, when New York reduced the price by half. 63

Just as the New Hampshire leaders were the beneficiaries of the original grants, New York land speculators were elated at the opportunity to gain from the language of the Privy Council ruling. New York officials were set to earn new fees from the territory and speculators would gain the fertile lands of the territory. ${ }^{64}$ A New York speculator who acquired 67,000 acres altogether, ${ }^{65}$ James Duane was chief among the group disputing the New Hampshire Grants and was supportive of New York claims in the territory. He would later become a leader on the issue as a New York delegate to Congress. Unlike their New Hampshire foes, New York speculators armed themselves with four key traits, as defined by Alexander. He wrote that they were girded with "wealth, prestige, influence with the British authorities, and a sound legal case."66 Rumors of land-jobbing by New Yorkers, despite the disproval of the royal government, gave New Hampshire grantees hope for a future case. ${ }^{67}$ Samuel Robinson dealt a further blow to the New Yorkers when his Society for Propagating the Gospel petitioned the royal government. He did so because the New York grants did not offer the Society any reserved shares, unlike the New

\footnotetext{
63 Taplin, 9-10.

${ }^{64}$ Alexander, 69.

65 Ibid., 70.

${ }^{66}$ Ibid., 76.

67 Williamson, 12.
} 
Hampshire Grants. This petition led to a royal order to cease new grants, ${ }^{68}$ but on a long-term basis, the struggle for New York claims in the territory remained strong.

Behind speculators like Duane was New York Governor George Clinton, who served from 1777-1795 and 1801-1804 as both royal governor and state governor. He had a long career in early American politics and, in time, became Vice President under Thomas Jefferson and James Madison. Clinton biographer John P. Kaminski described Clinton as having "a blind spot when it came to Vermont," never seeing "the parallel between Vermont's struggle for independence and America's." ${ }^{69}$ It remained Clinton's view that Vermonters were traitors and insurgents. ${ }^{70}$ This perception of the Vermont question came to define the New York position on the territory throughout the controversy. Uncompromising and unwilling to capitulate, Clinton wrote that New York must "in no Instance ... acknowledge the Authority of Vermont unless where there is no alternative left between Submission and inevitable Ruin." ${ }^{.11}$ As early as 1779, he expected to take the controversy to its bitter end, and he certainly did just that.

While New Yorkers had won lawsuits ejecting New Hampshire tenants, the settlers-led by Ethan and Ira Allen — refused to accept defeat. ${ }^{72}$ The Allen siblings had land interests in the region, but they also accepted the mantle of leadership of a burgeoning political and military movement. The Green Mountain Boys, a "band of insurrectionists," led by "bluster, swagger,

68 Alexander, 74.

69 John P. Kaminski, George Clinton: Yeoman Politician of the New Republic (Madison, WI: Madison House, 1993), 64.

70 Kaminski, 64.

${ }^{71}$ George Clinton to Samuel Minott, May 14, 1779, in James A. Holden and Hugh Hastings, eds. Public Papers of George Clinton, 10 vols. (New York: State of New York, 1899-1914), 3: 814. 72 Alexander, 75-76. 
and oaths" formed a key part of this movement. ${ }^{73}$ The group "made life so miserable for the few persons who tried to settle on the basis of New York titles that [the settlers] soon abandoned the New Hampshire Grants." 74 Before Ethan Allen's election as commander of the Green Mountain Boys, the Allens “apparently began to purchase Grants lands as early as 1762, always acquiring Wentworth titles rather than the more respectable but more expensive New York patents ... and the Allens soon became the most prominent anti-New York activists and speculators on the Grants."75 The 65,000 acres of land held by Ira Allen's Onion River Land Company was the largest in the New Hampshire Grants, but as historian J. Kevin Graffagnino acknowledged, "the continued success ... depended on keeping New York off the Grants."76 While their personal interests were intertwined with the New Hampshire Grants, "the Allens and their followers, without mentioning their own speculative interests, were able to convince the settlers that New York with its quit rents, limited representation, and land jobbers was taking their sustenance from them." 77 This growing anti-New York party pioneered the movement toward Vermont independence and, in time, local conventions developed into the non-recognized state.

March 1775 marked the first explicit mention of potential Vermont independence, and the national Declaration of Independence of July 1776 meant that Vermonters looked to the new Congress for recognition rather than the British government. Vermont held more conventions

\footnotetext{
73 Williamson, 36. The author notes that the violence of this movement is not often called to attention. In the Foreword (vii), the editor noted that the Green Mountain Boys were often the centerpiece in histories of Vermont, to the detriment of the history of economic and social forces. 74 Taplin, 14.

75 J. Kevin Graffagnino, “'The Country My Soul Delighted in': The Onion River Land Company and the Vermont Frontier," The New England Quarterly 65 (Winter 1992): 30-31.

76 Ibid., 33, 35.

77 Taplin, 13.
} 
throughout 1776, and independence became even more realistic when representatives from all across the state met. ${ }^{78}$ Progress in these conventions was not because of the need to bring broad representatives, as "the founders of Vermont had to create a state where no true community had existed." ${ }^{79}$ With a British siege of Fort Ticonderoga imminent in early 1777, attendance at the various conventions decreased as aid to the war effort from the New Hampshire Grants became essential. ${ }^{80}$ The controversy to this point had been defined by land disputes, but with the national declaration of independence, Allen's independence effort became about the ideology of the American Revolution as much as it was about land interests.

While the Allens made an effort to bring the New Hampshire Grants together, factions also still existed within New York. Outside of the Allens themselves, one of the key groups in the Grants was the College Party. Centered around the northern part of the Connecticut River, close to Dartmouth College, the group "was willing to affiliate with any jurisdiction which would comply with its demand that the Connecticut River Valley be united." ${ }^{1}$ This group would be a source of internal opposition throughout the controversy, and it often undermined Ethan Allen's ability to act decisively. Other groups on the outer edges of the Grants, in northern Gloucester County and southeastern Cumberland County, also prevented Vermont from achieving unanimity in favor of independence. ${ }^{82}$

\footnotetext{
78 Taplin, 20-21.

${ }^{79}$ Peter S. Onuf, "State-Making in Revolutionary America: Independent Vermont as a Case Study," The Journal of American History 67 (March 1981): 799.

80 Williamson, 60.

81 Taplin, 2.

82 Taplin, 28-29.
} 
A divide existed between the frontier attitude in the New Hampshire Grants and the upper-class conservative attitudes of New York, and when New York's new constitution showed that "the basic nature of its governing group was unchanged," Vermonters became even more willing to make the break from New York. ${ }^{83}$ In addition, congressional action of May 1776 encouraged supporters of Vermont independence by urging the formation of states, acting "for the people rather than as an agent of thirteen separate states." 84 Congress here recommended that any colony without an existing government should create an independent government which would "best conduce to the happiness and safety of their constituents in particular, and America in general." $\$ 85$ The culmination of these events led to Vermont's declaration of independence on January 15,1777 by a unanimous vote of a convention in Westminster, Vermont, ${ }^{86}$ but some residents of the Grants were still not on board. Ultimately, once-opposing groups were unified by events in Albany. An April 1777 New York state constitution that was "wholly unacceptable to the majority of the Grants inhabitants" 87 created unity and shifted momentum in favor of Vermont.

While the convention was brief and left much unfinished, its decision to abandon the rule of both Britain and New York had a lasting impact. The language of the declaration was strong and said that "an infringement on [residents of the New Hampshire Grants'] rights is still

83 Ibid., 18.

${ }^{84}$ Richard B. Morris, "The Forging of the Union Reconsidered: a Historical Refutation of State Sovereignty over Seabeds," Columbia Law Review 74, 6 (1974): 1068-1071.

85 May 10, 1776, in Worthington C. Ford, et. al., eds., Journals of the Continental Congress, 34 vols. (Washington, D.C.: Library of Congress, 1904-1937), 4:342. Hereafter cited as JCC.

${ }^{86}$ Williamson, 60.

87 Ibid., 61. 
meditated by the state of New-York." 88 So the new state, called New Connecticut at the time, had to prove its legitimacy. As Onuf stated, moving into this new phase of creating an independent government, Vermont remained "hard pressed to convince the populace that it had a right to govern itself and that the constitution had any legal force." 89 This problem would be the first of many challenges to face an independent Vermont. The first step to proving their own legitimacy — after changing their name to Vermont — was the creation of a state constitution. As noted in the previous section, Maier and Wood each made note that Vermont's effort toward crafting their constitution was influenced by other states, especially Pennsylvania. ${ }^{90}$ According to Taplin, "in almost every feature and particularly in making the legislature the dominant branch of government, the document was the antithesis of the New York constitution." 91 Much as the New York government prepared itself for constant opposition to the New Hampshire Grants, the new state government in Vermont prepared itself for constant opposition to New York.

Approved just six months after the national Declaration of Independence, Vermont's declaration mentioned the national declaration and the reaction of the new Vermonters to the national declaration. ${ }^{92}$ This reference made it clear that Vermont's actions were tied to a larger national movement. As Taplin noted, "Vermont's advance toward independence had not taken place in a vacuum ... It had grown with the American surge for separation from the Crown and events elsewhere on the continent were often a direct impetus to action in Vermont."93 As the

\footnotetext{
88 "Vermont Declaration of Independence" in John A. Williams, ed., The Public Papers of Governor Thomas Chittenden (Montpelier, VT: Vermont Secretary of State, 1969), 42.

89 Onuf, "State Making," 799.

${ }^{90}$ Maier, 275, see footnote. 22; Wood, Creation of the American Republic, 161-63

91 Taplin, 31.

92 Papers of Thomas Chittenden, 42.

93 Taplin, 22.
} 
Continental Congress took up the issue, it remained to be seen whether the delegates to Congress would embrace these revolutionary ideas when handling the Vermont controversy.

It is important to note that these events unfolded in conjunction with numerous events across the new United States throughout the 1770s and 80s. Many of these events took up significantly more time than the Vermont controversy and were influential on the institutional development taking place at the time. New York delegate Gouverneur Morris described the schedule of Congress during the heat of war: "At present three Days in the Week are set apart for the Treasury and Finances, two more for the Consideration of foreign Affairs, add to this that Congress is also an executive Body."94 The problems continued even after the war, as Congress was made to handle a growing national debt, taxation, commerce regulation, and other land disputes. In addition to these issues, Wood also described an existential crisis among the Founders, because the revolution was "a utopian effort to reform the character of American society and to establish truly free governments, men in the 1780's could actually believe that it was failing."95 The Vermont controversy was tied directly to both the policy-based and existential issues of the Critical Period. As historian Richard B. Bernstein noted in his 1987 Are We to Be a Nation? The Making of the Constitution, the controversy weakened the Confederation as delegates perceived that "problems affecting their own states were not treated with equal urgency by delegates from other states." 96 Bernstein was clear that because "land was the most durable and reliable measure of wealth and power in eighteenth-century America, both for

\footnotetext{
94 Gouverneur Morris to Robert R. Livingston, August 17, 1778, LDC 10:468.

${ }^{95}$ Wood, Creation of the American Republic, 395.

${ }^{96}$ Richard B. Bernstein and Kym S. Rice, Are We to Be a Nation? The Making of the Constitution (Cambridge, MA: Harvard University Press, 1987), 86.
} 
individuals and for the states," land controversies were deeply intertwined with the most important issues in the Continental Congress. ${ }^{97}$ Relying upon the letters of delegates to Congress, the next chapter of the present study analyzes how Congress treated the issue of Vermont's independence until their entry into the Union in 1791.

\section{4. "A Perpetual Broil": The Continental Congress}

The Continental Congress formed the battleground for debates which shaped the early course of United States government. One debate occurred over the Vermont question. While the question was by no means first on the minds of most delegates in comparison to the Revolutionary war or financial issues, it was unique in that it confronted the brand-new legislators in a brand-new nation with the challenge of determining the extent of their own jurisdiction. The result was frustrating and unclear. Yet the exercise of engaging in this debate offered insight on how delegates viewed their own power. Mostly, they displayed a reluctance or even unwillingness to engage with the debate. "I shod not much care if the Devil had them all," wrote William Whipple in a 1777 letter which reflected the attitude of most delegates. ${ }^{98}$ While his impatience and annoyance was palpable in the earliest stages of the controversy, the controversy developed far beyond what any delegate imagined. Through an analysis of the letters of delegates to congress from 1777 to 1788 , the Vermont crisis may be understood as a key part of the development of how America's legislators actually governed themselves. This section makes such an analysis.

\footnotetext{
97 Bernstein, 87

98 William Whipple to Josiah Bartlett, April 7, 1777, LDC 6:550.
} 


\section{"A moot-point": Early Action in Congress}

In May 1776, the New Hampshire Grants presented their first petition to a reluctant committee of five in the Continental Congress. ${ }^{99}$ This committee recommended cooperation with New York, but said that "such submission ought not to prejudice the right of them or others to the lands in controversy," hoping to avoid a conflict among rival colonies. ${ }^{100}$ With the recommendation as a key example, Taplin noted that "most delegates felt that the problem was best left alone in order to antagonize neither New York nor New England, and a precedent was thus established of avoiding the Vermont issue as much as possible."101 This first interaction was typical of the early stages of the controversy in Congress. This petition and New York's remonstrance contributed to Vermont's ability to declare their independence and create their own Constitution. ${ }^{102}$ However reluctant Congress was to act to resolve the crisis, the revolutionary spirit of the era promoted Vermont's continued defiance.

Less than a year after the national Declaration of Independence, New York delegates moved to quell the same spirit among Vermonters "led by their Passions to bring on Revolutions." ${ }^{\prime 103}$ During an active military conflict, this point of view was not unreasonable for the new state to take. "Good Policy must therefore dictate to all the Necessity of discouraging this factious and turbulent Spirit, and of securing to every State its proper Rights and Jurisdiction, as well as against internal as foreign Enemies," wrote the New York delegates. ${ }^{104}$

\footnotetext{
99 Taplin, 37.

100 May 30, 1776, JCC 4:405.

101 Taplin, 38.

102 Ibid., 40. The framework of the government in Vermont was further established in the previous chapter.

${ }^{103}$ New York Delegates to the New York Council of Safety, May 23, 1777, JCC 7:112.

104 New York Delegates to the New York Council of Safety, May 23, 1777, Ibid. 7:112.
} 
New York was eager to display strength and resolve to bring the question to a quick and favorable conclusion, but other delegates were less convinced that a final determination could be reached. "I do not however think that New York has much to boast of," wrote Massachusetts delegate James Lovell. "It is still a moot-point whether the people of the Grants belong to Massachusetts, New Hampshire, or New York." 105 Despite New York's desire for swift action, Lovell's view proved more common among the delegates as a whole.

Nevertheless, the New Yorkers persisted alone until 1778, when secession efforts in Western New Hampshire brought others states back into the fold. New York Governor George Clinton drove the push for an answer on the Vermont question. ${ }^{106}$ "I am exceedingly concerned to learn that Congress have not yet taken up our Controversy ... and that we are not of Course to speedily Expect an Explicit Declaration of the Sense of Congress on that Subject," he wrote to the delegates. ${ }^{107}$ Attempting to avoid the idea that any delay was their fault, the New York delegates wrote back with a proposed resolution which was not discussed or passed. ${ }^{108}$ However, Clinton placed midst of the blame on Congress as a whole. He was often unsatisfied that Congress "was not able to afford a Moment to an Affair in which one of the States is so deeply Interested \& the Honor \& perhaps future Peace of the whole so intimately concerned."109

105 James Lovell to William Whipple, July 7, 1777, $L D C$ 7:316.

106 Throughout the controversy, Clinton was on the receiving end of letters from a changing group of New York delegates assuring a speedy resolution.

107 George Clinton to Gouverneur Morris, July 7, 1778, Clinton Papers 3:531.

${ }^{108}$ New York Delegates to George Clinton, July 21, 1778, LDC 10:331-33.

109 George Clinton to Gouverneur Morris, July 7, 1778, Clinton Papers 3:531. Congress was quite busy during this time period due to the war effort, however, Clinton's impatience may have also stemmed from constant assurances from delegates on a speedy resolution, such a Morris's promise that "a spirit of Justice reigns throughout Congress inclining to do every Thing necessary to quiet the unhappy Disturbances in the North Eastern Part of our State." (Morris to Clinton, June 23, 1778, LDC 10:185-86). 
New Yorkers often placed blame upon the "designing men" whose private interests allegedly got in the way. ${ }^{110}$ At one point, Clinton wrote to President of Congress Henry Laurence that a resolution was "necessary to prevent the immediate Shedding of Blood; and with out it I fear all those Calamities and misfortunes which are the natural attendants of a civil war."111 This rhetoric was commonplace from New Yorkers, and Clinton's letter suggested a desire to end the conflict before his nightmare scenario came to fruition.

Out of Clinton's impatience came one casualty: the congressional career of Morris. Although he sought to be strategic in this early effort, his work was not well-received in New York. Seeing weakness in the New York cause, he wrote that "the prejudices of the people are against us so are their interests" and suggested meeting some Vermont demands in order to keep them as a part of New York, espousing the philosophy that "A good government, a free one I mean, will always command the wealth of its people." 112 According to Taplin, writing of Morris, "the determination of Vermonters to establish independence impressed him and he doubted whether they could be diverted from it by force." 113 His philosophy of good government was in line with the thinking of other long-term nationalists such as New Yorker Alexander Hamilton and Virginian James Madison. While it was ultimately correct, this attitude cost him his job as a delegate. "I know I shall be charged by my Enemies," he wrote to New Yorker Robert R. Livingston before being recalled. ${ }^{114}$ At this moment in the crisis, interstate rivalries and personal land interests overshadowed long-term thinking.

110 Gouverneur Morris to George Clinton, March 4, 1778, LDC 9:217.

111 George Clinton to Henry Laurence, July 8, 1778, Clinton Papers 3:535.

112 Gouverneur Morris to George Clinton, March 4, 1778, LDC 9: 217.

113 Taplin, 87.

114 Gouverneur Morris to Robert R. Livingston, August 17, 1778, LDC 10:468. 
"The most virulent jealousy": Rivalry with Eastern Delegates

Much as a "seaboard against backcountry" attitude served as a background to the conflict between the inhabitants of Vermont and their New York opponents, interstate conflict played a major role as the Vermont issue was debated in Congress. This conflict was not out of the ordinary, as Peter Onuf noted that, at this time period, "pervasive mistrust crippled Congress, which therefore was unable to support and legitimize particular state claims or uphold the interests of the states collectively." 115 At the center of this conflict was a rivalry between the New England states and New York. ${ }^{116}$ Letters from delegates indicate the existence of this rivalry in the early stages of Congress. "I can by no means think that this attempt to dismember our State will be countenanced by Congress," wrote New York delegate William Duer to the New York Convention, “tho' I am sorry to say, that I can very easily perceive that Individuals from the Eastern States mean to support Messrs. Allen in their extravagant Pretensions."117 According to Taplin, this perception was a part of the reason New York sought to utilize Congress as a means to bring their claims into the open and force a resolution of the issue. ${ }^{118}$

One of the early examples of conflict with New England was the congressional reaction to a letter from Dr. Thomas Young. Young was a doctor in Philadelphia and an advisor to Vermont whose letter "so cogently presented the Vermont case that Congress was aroused to action."119 The letter intimated that Vermont need only comply with the May 10, 1776

115 Onuf, The Origins of the Federal Republic, 150.

116 New England states Massachusetts, Connecticut, and Rhode Island were often referred to broadly in letters as Eastern States. New York's allies on the issue- the Souther states-would continue to emerge throughout the debate.

117 William Duer to the New York Convention, April 17, 1777, LDC 6:601.

118 Taplin, 47.

119 Ibid., 50-52. 
congressional resolution ordering state constitutions to be drafted in order to achieve statehood. ${ }^{120}$ After its circulation, New York sought resolutions condemning Vermont, which passed with some opposition from New England. ${ }^{121}$ From the New York delegates' perspective, the New Englanders' efforts were misguided as James Duane wrote that those states "drew on the merits of our Title, tho' the Congress had only to do with the Exercise of Jurisdiction." ${ }^{122}$ While Duane was correct in his statement that New England's efforts to block the measures backfired, he did not anticipate the importance of the opposition of the New England delegates. Samuel Adams wrote that the resolutions were meant to "gratify New York" over "A matter which is not worth your while to have explained to you." ${ }^{123}$ Clearly, the New England delegates had no interest in settling New York's disputes. Roger Sherman of Connecticut offered especially sharp criticism of the resolutions, precipitating early tensions ${ }^{124}$ and showing New York's support to be thinner than its delegates perceived. Yet these early resolutions and division were just the beginning; during real crises, the debate in Congress proved even more remarkable.

\section{"Into the Snare": The Western Towns Secede}

While New York delegates had seen their cause lose its significance in Congress, a new development along the Connecticut River served as a blow to the Vermonters' cause and bolstered a coalition in Congress around New York. In the summer of 1778, sixteen western New Hampshire towns, led by the College Party, voted by slim majorities to secede and join

120 Ibid., 51.

121 June 30, 1777, JCC 8:509-513.

122 James Duane to Robert R. Livingston, June 26, 1777, LDC 7:253.

${ }^{123}$ Samuel Adams to Richard Henry Lee, June 26, 1777, $L D C$ 7:264.

124 James Duane to Robert R. Livingston, July 1, 1777, $L D C$ 7:279. Duane noted that "some of our neighbors (R.S. in particular) discovered an Earnestness and Solicitude that did not belong to a Judge between a State and its discontented members." 
Vermont. Vermont's legislature approved the addition on June 11, 1778. ${ }^{125}$ "The Hampshire Grants by Receiving \& Countenancing them, have fell into the Snare laid for them by New York," wrote New Hampshire delegate Josiah Bartlett. ${ }^{126}$ While the College Party did not expect pushback, New Hampshire Governor Meshech Weare received concerns from those in the towns who still remained loyal to New Hampshire and fought the move. ${ }^{127}$ Weare wrote that he was willing to settle the issue by violent means, saying that "very possib[ly] the sword will decide it." 128 This threat forced the issue to come before the Continental Congress, where the Vermont cause suffered.

Bartlett wrote to Weare in September of 1778 with details on the reaction of other delegates, although the issue had not yet come before Congress officially. "Those Delegates to whom I have Communicated the affair," he wrote, "Seem surprised at the ungenerous and impolite Conduct of Vermont, and I have reason to Believe they will find few or none in Congress that will Justify their Conduct or Espouse their Cause." ${ }^{129}$ Bartlett was correct in his forecast of congressional reaction to the secession of the sixteen towns; however, a proper course of action remained in question for the delegates. Within a few weeks Bartlett informed Weare that "Every person who Spoke on the Subject Severely Condemned the Conduct of the Revolted Towns \& of Vermont; What was proper to be done was all the difficulty." 130 This inability to decide on a proper reaction was common in Congress, and Bartlett pointed to a general desire to

\footnotetext{
125 Taplin, 103.

126 Josiah Bartlett to Meshech Weare, August 4, 1778, LDC 10:388-89.

127 Taplin, 103-104.

128 Weare to Bartlett, August 8 1778, Meshech Weare Papers, Massachusetts Historical Society, Boston, MA.

${ }^{129}$ Bartlett to Weare, September 8, 1778, LDC, 10: 601.

130 Bartlett to Weare, September 26, 1778, LDC 10: 693-695.
} 
put off the issue as long as possible. "I believe it is the Desire of the major party of the members of Congress (if possible) to keep off the final Decision of the old Dispute Concerning the New Hampshire Grants to Some future time when it may be Setled without any Danger to the Common Cause," he wrote. ${ }^{131}$ While this statement can be directed at congressional handling of the Vermont question throughout the controversy, it was the first complaint by a non-New Yorker about the pace of action on the issue in Congress. Ethan Allen promised to take the issue back to Vermont and encouraged Bartlett to delay congressional action until the Vermont legislature could meet to rescind the offer of union with the towns.

Eventually, even Vermont ally and Connecticut delegate Richard Sherman became involved in the push to end the "dangerous and alarming"132 efforts to join Vermont, and he confirmed that it hurt the overall cause of Vermont in a letter to Elisha Payne, a judge and leader of the towns. A true republican of the late eighteenth century, Sherman expressed faith that the constitution of each state could be amended by the will of the people, calling secession unnecessary. He wrote that "for people Inhabiting within the known \& acknowleged boundaries of any of the united States to Separate without the consent of the State to which they belong, appears to me a very unjustifiable violation of the Social compact, and pregnant with the most ruinous consequences ... it appears to me indispensibly necessary that civil Government Should

${ }^{131}$ Ibid., 693-695.

132 Roger Sherman to Elisha Payne, October 31, 1778, LDC 11: 152. As was characteristic of New England delegates, Sherman was mostly non-committal on the issue, but was possibly friendly to the Vermont cause. "Whether the State of New Hampshire or New York have a right of Jurisdiction over the New Hampshire Grants on the west Side of Connecticut River, or whether by the neglect of the former to Claim and Support its Jurisdiction against the latter, the people have a right to form themselves into a distinct State, I shall not give any opinion, those questions will I Suppose at a proper time be judicially decided." 
be vigorously Supported." 133 The argument on state jurisdiction over the New Hampshire Grants was reasonable, but secession worried Sherman and other delegates to Congress. Even Vermont allies were fearful of the precedent set by congressional approval of secession. In autumn of 1778, Allen and Bennington denounced the actions of the sixteen towns.

Despite this denunciation, New York sought to take advantage of dissent within Vermont, as not all leaders agreed with Allen's announcement. According to a letter from New York delegates to George Clinton in early December 1778, John Wheelock, a prominent leader in the sixteen towns, was "complaining that Allen had no authority to make the before mentioned Declaration; that they utterly renounced it and adherd to their Revolt from New Hampshire."134 This crack in the unity of Vermont leadership was a positive sign for New Yorkers, who thought that the dispute "renders ridiculous the Plan which Allen and his adherents boasted of as decisive." 135 As confident as ever that the controversy would be settled by Congress, New York placed delegate John Jay in charge of the effort to resolve the issue. ${ }^{136}$ Jay was soon forced to delay his work because the Congress elected him to the Chair, and he wrote to Clinton that "the season for bringing on the affair of Vermont is not yet arrived," but assured him that his "Endeavors shall not be wanting to bring it to a Termination satisfactory to NewYork."137

While New York delegates prepared themselves to do battle in Congress, New Hampshire delegates were not in harmony with New York's perspective. New Hampshire delegates feared capitulating to the interests of New York delegates. In that regard they shared a cause with the

\footnotetext{
133 Ibid., 152.

134 New York Delegates to George Clinton, December 1, 1778, LDC 11: 273-274.

135 Ibid., 273-274.

136 Ibid., 273-274.

137 John Jay to George Clinton, December 10, 1778, LDC 11: 325.
} 
Vermonters and were willing to accept Allen's desire to solve the secession issue. This wariness towards New York's dominance led Whipple to write Weare his thought that "nothing will effectively settle the dispute but New Hampshires opposing her claim to that of New-York; even if she should afterwords (supposing the decision to be in favor of New Hampshire) agree that the grant on the west side of the River should be a separate State." ${ }^{138}$ In the context of a struggle for dominance between New York and New England, this statement made sense. Whipple endorsed this method because, he wrote, "in that case New Hampshire would have it in her power to settle the line to her satisfaction, and perhaps avoid some disagreable disputes that may otherwise arise." 139 Whipple later recommended that a lawyer be hired to compete with Jay, so that New Hampshire would not be left out in the ensuing debate. ${ }^{140}$

As the issue became more prominent, delegates in Congress saw three possible conclusions to the question: New York earning jurisdiction, New Hampshire earning jurisdiction, or a separate state being formed. Whipple thought the first possibility to be the most unfavorable because of Vermonters' presumably negative reaction to being "compeled to Unite with a people for whom they have an inextinguishable aversion, arising from injuries they have suffered, by the most cruel acts of Injustice." ${ }^{141} \mathrm{He}$ also thought that congressional sanction of a separate state would only exacerbate the secession cries of western New Hampshire and thus thought that "every one who has the Happiness of Mankind, \& Peace \& Welfare, of New-Hampshire at Heart will be convinced of the propriety of her claiming the jurisdiction ... I have reason to think

\footnotetext{
${ }^{138}$ William Whipple to Meshech Weare, December 8, 1778, LDC 11: 308.

139 ibid., 308.

${ }^{140}$ William Whipple to Meshech Weare, December 14, 1778, LDC 11: 339-340.

141 Ibid., 339-340. This was another bold statement rebuking New York's claims over Vermont.
} 
Congress will be hard pressed to do something in the matter." ${ }^{142}$ In the end, Congress took no decisive action as a result of the secession of the New Hampshire towns; however, it led to further study of the issue in Congress. In addition, the controversy forced delegates to reveal their true thoughts on the matter and demonstrated the divide between New York and New Hampshire delegates.

“Our whole Strength”: New York's Resolutions

Revitalized by the secession issue, New York entered 1779 expecting Congress to decide the matter once and for all. "I wish to appear with our whole Strength," wrote Jay to Clinton. ${ }^{143}$ The usual delays remained for delegates, however. According to New York delegate William Floyd, Congress put off early action "while the grand business of Finance was under consideration," 144 but Congress did consider resolutions which Jay called "temperate \& founded on plain Principles."145 While New York delegates were hopeful about the resolutions, ${ }^{146}$ Jay's notes on the debates over them indicated hesitancy toward a firm decision on the part of some delegates. A key concern in these debates was whether Congress-because the Articles of Confederation were not complete — had the power to decide jurisdictional questions. ${ }^{147}$ Onuf, in The Origins of the Federal Republic, wrote that before the Articles, "Congress had no constitutional standing at all"; however, "Congress also accumulated powers in an ad hoc fashion, as it responded to contingencies."148 Jurisdictional decision-making was not a power

\footnotetext{
142 Ibid., 339-340.

143 John Jay to George Clinton, December 19, 1778, LDC 11: 360-61.

144 William Floyd to George Clinton, January 5, 1779, LDC 11:416-17.

145 John Jay to George Clinton, May 22, 1779, LDC 12: 509.

146 William Floyd to George Clinton, May 25, 1779, LDC 12: 530.

147 John Jay's Notes of Debates, May 29, 1779, LDC 12: 553.

148 Onuf, The Origins of the Federal Republic, 7.
} 
Congress was prepared to accumulate, and although it was not as strong an action as New York sought, Congress decided to send a committee to Vermont "to enquire into the Reasons why they refuse to continue Citizens of the Respective States which heretofore exercised Jurisdiction over that district and to take away prudent measure to promote an amicable Settlement of all differences, and prevent divisions and Animosities so prejudicial to the United States." ${ }^{149}$ This moderation proved beneficial to New York, as it seemed too reasonable for any member to vote against. ${ }^{150}$ However, Duane noted that placing so much stake in New England delegates was "not a desirable Hazard,"151 and Massachusetts delegate James Lovell reported that Clinton was unhappy with the measure, despite his state's delegates supporting it. ${ }^{152}$

Clinton's concern was unfounded as the committee reported that the Vermonters "were heartily willing on Condition that Time was given them $\&$ due Notice to represent their Case, to Submit themselves \& finally to abide by the decision of the United States in Congress assembled." 153 Lovell noted that the issue remained "delicate," as Vermonters "expect to be heard regularly before any formal Decision is made concerning them," yet their recognition as a legitimate party could "wound the Feelings"” of New York. ${ }^{154}$ The return of the committee from Vermont also troubled New Hampshire delegates, who knew that if New Hampshire did not make a claim to Vermont, it would "assuredly be annex'd to N.Y. which I am sure must be

149 John Jay to George Clinton, June 1, 1779, LDC 13: 3.

${ }^{150}$ New York Delegates to George Clinton, June 1, 1779, LDC 13: 7-8.

${ }^{151}$ James Duane to George Clinton, June 2, 1779, LDC 13: 12. He was concerned that the committee could turn the opinion firmly against New York, but thought this solution "preferable to the Effusion of American Blood."

152 James Lovell to Samuel Adams, June 21, 1779, LDC 13: 93. He added: "I think that worthy Gentleman has not the necessary Coolness in this Business."

${ }^{153}$ Committee of Congress Report on Vermont, July 13, 1779, LDC 13:201-03.

154 James Lovell to Samuel Adams, July 13, 1779, LDC, 13:209. 
attended with disagreeable consequences not only to N.H. but other Eastern States." 155 They had earlier pleaded for a representative from the state to handle the matter exclusively. ${ }^{156}$ Jay saw that both New York and New Hampshire needed to agree to allow Congress to settle the boundary and "by act of Legislature [empower Congress] to adjust the disputes with the people of the grants on equitable and liberal principles," realizing that congressional jurisdiction was "the great point."157 He hoped this could settle the issue of the limits of congressional power to handle jurisdictional matters. Before the final resolutions passed, Jay became frustrated enough to suggest that New York tax revenue be withheld from Congress until action was taken, even though he acknowledged it would break from his desire to promote the common interest. "I would nevertheless detain every shilling of it till justice be done the State," wrote Jay, "and for this purpose Congress should be immediately authorized by law to do it effectually, unembarrassed by useless and perplexing provisoes and reservations."158 In late September 1779, New York earned an apparent victory when Congress passed resolutions about the controversy which laid out a path for a final decision. ${ }^{159}$

At the heart of the resolutions was the desire to tie the Vermont controversy to the reasonable maintenance and security of state rights, which Congress saw as "one of the great objects of the Union of the United States of America."160 The key provisions of the resolution asked the involved states to pass legislation which would allow Congress to settle the

\footnotetext{
${ }^{155}$ William Whipple to Josiah Bartlett, August 3, 1779, LDC 13: 322.

156 William Whipple to Josiah Bartlett, June 4, 1779, LDC 13: 24.

157 John Jay to George Clinton, August 27, 1779, LDC 13: 419.

158 John Jay to George Clinton, September 2, 1779, LDC 13: 446.

${ }^{159}$ Samuel Bolten's Diary, September 23-24, 1779, LDC 13: 538.

160 Ibid., 552.
} 
jurisdictional claims, and also forbade the involved states from voting on the final decision. ${ }^{161}$ The resolution was not without teeth as it promised to enforce provisions disallowing any party from granting unclaimed lands. ${ }^{162}$ Soon after their passage, Jay wrote a detailed letter to Clinton with the resolution and his comments included. Knowing Clinton would not be completely satisfied by the resolutions, he noted that "it would not have been difficult to have obtained what some among us would call very spirited and pointed Resolutions, but wh in my opinion would have been very imprudent ones, because among other Reasons they wd. not have been unanimous." 163 The resolution made some concessions including the acknowledgment of an equal footing among the parties, but the resolutions gave New York the opportunity for the final decision they long desired.

"Hangs by the Eyelids": Enforcement Delayed

As was the norm, New York sought swift action on the new proposals. Jay thought that the resolutions would "establish perpetual Harmony" between the states, but hoped that the parties would not argue "about Triffles, or by unnecessary heats retard a Settlement satisfactory to all."164 Jay made this statement as the leader of a delegation confident that the tides were turning in New York's direction; however, what were "Triffles" to Jay were far more serious issues to other delegates. Lovell noted that while Massachusetts felt obliged to act under the circumstances, he himself hoped that his "State will never let Congress be a Tribunal to decide Bounds \& Right of Soil ... I think we have got so far [in the resolutions] without committing

\footnotetext{
161 Ibid., 547-553.

162 Ibid., 547-553.

163 John Jay to George Clinton, September 25, 1779, LDC 13: 548.

164 John Jay to George Clinton, September 29, 1779, LDC 13: 594.
} 
Enormities, in that Case."165 Massachusetts delegates noted to the Massachusetts Council that the pending Articles of Confederation offered better means to act on the matter, although their anti-New York bias must be noted. ${ }^{166}$ In addition, some delegates who admired Vermont's revolutionary cause frowned upon New York's attitude toward Vermont. New Jersey delegate wrote that "they talk of the Vermont-people as Great-Britain does of us . . . It is a childish Idea that a Majority in any Country ... should be governed by a Minority."'167 Like many delegates, he saw any attempt to force Vermonters to submit to New York as a path to violence, although he approved the terms of the resolution. "I will remember what I thought some years ago," he wrote, "that if I were oppressed by a Set of Land-jobbers and Aristocratical Gentry as those People were, I would die in the last Ditch rather than succumb to it." 168 He expressed sympathy for the Vermonters in their struggle against New York. These thoughts were by no means the norm, but New York's path to a decision was not as clear-cut as they would have enjoyed.

Jay took the liberty to send each involved state an identical resolution to pass, "lest variances which might be deemed important, should create Delay \& Dispute,"169 but New Hampshire and Massachusetts were more concerned with their own revived interests in the territory. While New Hampshire saw the potential for a gain in political and financial power from being given Vermont, they also saw the likelihood of it becoming a part of New York if they did not fight hard for the territory. ${ }^{170}$ This fear was of much concern to New Hampshire

\footnotetext{
165 James Lovell to Samuel Adams, September 29, 1779, LDC 13: 595-96.

166 to the Massachusetts Council, October 4, 1779, LDC 14: 20-21.

${ }^{167}$ William Churchill Houston to Robert Morris, March 6, 1780, LDC 14: 468.

168 Ibid., 468.

169 Jon Jay to George Clinton, October 7, 1779, LDC 14: 29.

170 Woodbury Langdon to Meshech Weare, October 12, 1779, LDC 14: 58.
} 
delegates. "It . . becomes Necessary for the State of N. Hampr. to Exert every Nerve to prevent a State by her vast Extent of Territory, and Still Greater Claims, already Troublesome to her Neighbors and Tyranical to the last degree over all such as are unhappy victims of their resentment - from Extending Jurisdiction as to Circumvolve the State of New Hampr," wrote New Hampshire delegate Nathaniel Peabody of the resolution he considered to be "hatched up by N.Y."171

Early into 1780, new New York delegate Ezra L'Hommedieu wrote to Clinton that some delegates "have received information from the New Hampshire Grants [that] they are determined not to submit to the Decision [of Con]gress, their Claim to Independence; but have [named] Agents to send to Congress, with offers to confederate with the United States, or such of them as are willing to confederate with Vermont." ${ }^{172}$ Lovell confirmed that delegates had arrived to make an offer to join the Union, but did not submit to the main question of the September 1779 resolutions; hearings on the 1779 resolution were thus delayed even longer. ${ }^{173}$ On March 2, Congress agreed to take the matter under consideration with all parties, ${ }^{174}$ but were forced to postpone as nine states were not in attendance. ${ }^{175}$ In April, New York delegate Philip Schuyler wrote to Clinton that "the Vermont business still hangs by the Eyelids" because Maryland and Delaware did not have representatives present so a vote could not be taken. ${ }^{176}$ New York was frustrated by the apparent lack of motivation to prevent what they viewed as "a usurpation which

\footnotetext{
${ }^{171}$ Nathaniel Peabody to Meshech Weare, October 26, 1779, LDC 14:125.

172 Ezra L'Hommedieu to George Clinton, January 21, 1780, LDC 14: 357.

173 James Lovell to Samuel Adams, February 1, 1780, LDC 14: 384.

174 March 2, 1780, JCC 16: 222.

175 March 21, 1780, JCC 16: 273.

176 Philip Schuyler to George Clinton, April 18, 1780, LDC 15: 52.
} 
both in its principles and its consequences has the most dangerous and alarming Tendency." 177 However, other delegates were far from alarmed by the issue and saw many more pressing issues on their docket. Maryland delegate Daniel of St. Thomas Jenifer wrote that he hoped that "Congress have more wisdom then to take final Order in this business, before our independence is established; We have business enough on our hands without carving out more of this time."178 In this spirit, the delegates postponed the issue until the second Tuesday in September, although New York tried to get an earlier date. ${ }^{179}$ New Hampshire contributed to this delay as well because their delegate was not present, ${ }^{180}$ and disappointed New York delegates wrote that "to have pushed it with too much warmth would have answered no other purpose that expose us to the censure of wishing to take advantage of our antagonists." ${ }^{181}$ However, it appears that New York delegates had pushed too hard as numerous delegates wrote expressing some annoyance with the loss of focus on other issues in Congress. ${ }^{182}$

New York's fear of failure continued to grow as it had been over a year since the September 1779 resolutions had passed and no action had been taken. John Morin Scott wrote "I am of Opinion the sooner we press the Matter to its Crisis the better, For I fear the Interest agt. us is growing. Not that I imagine a Majority will expressly decide agt. Us, but that it may eventually be done by procrastination." ${ }^{183}$ Debate finally began, but Duane was quickly

177 New York Delegates to George Clinton, June 5, 1780, LDC 15: 256.

${ }^{178}$ Daniel of St. Thomas Jenifer to Thomas Sim Lee, June 5, 1780, LDC 15: 251-52.

${ }^{179}$ Samuel Huntington to Certain States, June 6, 1780, LDC 15: 262; John Morin Scott to Ezra L'Hommedieu, June 6, 1780, LDC 15: 274.

${ }^{180}$ June 9, 1780, JCC 17:499.

181 New York Delegates to George Clinton, June 16, 1780, LDC 15: 337.

182 Samuel Adams to John Lovell, September 15, 1780, LDC 16: 64-65; Ezekiel Cornell to Nathanael Greene, September 19, 1780, LDC 16: 87.

183 John Morin Scott to George Clinton, September 26, 1780, LDC 16: 113. 
convinced that the delegates "were disposed to support the Independence of our revolted Citizens ... But the Acts of our Antagonists \& the shameful prostitution of the disputed lands to gain party in some of the States have in my Judgement no inconsiderable weight"; therefore, he saw the need for New York to act on its own to manage the situation. ${ }^{184}$ Other delegates saw New York's dissatisfaction with the recent debate, and Rhode Island delegate Ezekiel Cornell wrote that "the gentlemen from New York did not like very well the sentiments of a Majority of members on the subject and will lett the affair rest until a change in members shall take place that will better suit their purpose," 185 and New Hampshire John Sullivan noted that the New Yorkers "have never mentioned it since \& it rests at present." 186 With the situation unfavorable, New York delegates were not present and New Hampshire delegate Samuel Livermore wrote that he was "very strongly impressed with an idea that this dispute will never be settled but by dividing the territory between N York \& us," but knew that any outcome would be difficult to implement to the satisfaction of all parties. ${ }^{187}$ With the controversy at a seeming standstill, and New York delegates momentarily out of the picture, a spark came to re-ignite the situation: a letter from British Secretary of State Lord George Germain. "Traytors to their Country": Expediency Acts

The shocking revelation in the summer of 1781 brought the Vermont question back onto the top of the docket of Congress. In a letter to General George Washington, Delaware delegate Thomas McKean quoted an intercepted letter from Germain to British General Sir Henry Clinton

\footnotetext{
${ }^{184}$ James Duane to George Clinton, October 7, 1780, LDC 16: 160.

185 Ezekiel Cornell to William Greene, October 24, 1780, LDC 16: 247.

186 John Sullivan to Meshech Weare, November 15, 1780, LDC 16: 340.

187 Samuel Livermore to Meshech Weare, June 26, 1781, LDC 16: 351.
} 
which read that "the return of the people of Vermont to their allegiance is an event of the Utmost importance to the Kings Affairs and at this time if the French and Washington really mediate an irruption into Canada may be considered as opposing an insurmountable bar to the attempt."188 Delegates reacted to the news and sought to handle the issue with a new sense of urgency. Sullivan wrote that he was "astonished at the proceedings of Vermont . . . I suppose whatever can be done here will be done in a week or fortnight at farthest." ${ }^{189}$ According to Taplin, Vermont's talks with Britain were not done with the end of joining Britain, but that "Vermont was playing a game of expediency and that any desire it had to desert the American cause arose not from love of England but from the fears that Congress would not accept its terms for in dependence and would be unsuccessful in the war."190 To a certain extent, the plan worked for Vermont, as evidenced by the statements of delegates at the time. St. Thomas Jenifer wrote at the time that "if we do not speedily allow them to be independant I fear they will join the Enemy."191 Events in New York and Massachusetts also conspired against New York's cause. Massachusetts passed a law which stated that they would give up their claim to the territory in favor of independence and the New York legislature's lower chamber also voted in favor of granting independence. ${ }^{192}$ The discovery of potential British involvement rendered the 1779 resolutions on Vermont impotent, and Congress adopted a different path. A committee of Congress submitted a

188 Thomas McKean to George Washington, July 17, 1781, LDC 17: 413.

189 John Sullivan to Meshech Weare, July 10, 1781, LDC 17: 396-97.

190 Taplin, 205.

${ }^{191}$ Daniel of St. Thomas Jenifer to Thomas Stone, July 23, 1781, LDC 17: 426. New Jersey delegates also asked for order "relative to the dispute of Vermont $\&$ the expediency of their being declared a free $\&$ independent State, I should be much obliged." (Elias Boudinot to Peter Wilson, July 28, 1781, LDC 16: 452.)

192 Ezra L'Hommedieu to George Clinton, July 31, 1781, LDC 17: 458. 
recommendation that Vermont be granted independence—-so long as they go back to their original claimed boundaries west of the Connecticut River and east of Lake Champlain. ${ }^{193}$ New York's delegates arrived late to the debate and found the controversy "in a manner Settled" upon the committee recommendation. ${ }^{194}$ In a memorial to Congress, the delegates reminded Congress of the 1779 resolutions and expressed a continued desire to follow procedure laid out within them despite the fact that other parties had not followed them. ${ }^{195}$ While their statements were bold and unpersuasive to other delegates, New York delegates challenged the other delegates to consider the implications of creating a new state out of an old one before voting, writing that "they can place their Principles on some Ground, and oppose Expediency and publick Safety to Justice and Right." 196 To them, the justice of preventing the new state was more important than expediency. Nevertheless, Congress appointed a committee to meet with Vermonters to discuss potential terms of independence, to be led by Vermont ally Roger Sherman of Connecticut. ${ }^{197}$ As congressional leaders pressured Clinton to support the resolution, ${ }^{198}$ his delegates wrote him with full expectations of a "Sacrifice of Jurisdiction," and could only hope to guarantee as much territory as possible. ${ }^{199}$

Much like New York's delegates, New Hampshire delegates became disheartened by the resolution of Congress. Echoing New York's arguments got them nowhere in the overall process, and they saw the door slowly closing on the New Hampshire Grants as a whole. Their

\footnotetext{
193 Roger Sherman to Josiah Bartlett, July 31, 1781, LDC 17: 461.

${ }^{194}$ New York Delegates to George Clinton, August 7, 1781, LDC 17: 483.

195 New York Delegates' Memorial, August 3, 1781, LDC 17: 468-471.

196 New York Delegates to George Clinton, August 7, 1781, LDC 17: 483.

197 Roger Sherman to Jonathan Trumbull, Sr., August 7, 1781, LDC 17: 484.

198 Thomas McKean to George Clinton, August 8, 1781, LDC 17:486.

199 New York Delegates to George Clinton, August 9, 1781, LDC 17: 488.
} 
concern became limiting Vermont to the west side of the Connecticut River. ${ }^{200}$ Livermore wrote to Weare that if only this limit could be established and Grafton county made part of New Hampshire, they "might be a happy state."201 A committee of Vermonters made up of Ira Allen, Jonas Fay, and Bezaleel Woodward met with Congress in mid-August and answered questions in agreement with the wishes of Congress. ${ }^{202}$ Vermont hoped to join the confederacy before settling any specific boundaries using the process laid out by the Articles of Confederation. This proposal went beyond Cogress's offer for independence. Eventually, the Vermonters returned home to seek a final answer. ${ }^{203}$ The tide had turned against New York, as even the often-friendly Southern states voted for the resolutions due to their recent invasion by the British Army, although they would vote to ask New York to relinquish willingly, given their view "that Congress has no authority to admit those people into the Federal Union as a separate State on the present principles."204 Despite the confidence of Congress that Vermont would soon be the fourteenth state, no official word had been heard from Vermont's representatives by the beginning of 1782 .

\section{“It Appears Very strange”: Vermont's Rejection}

By the end of January 1782, it became clear to the delegates in Congress that Vermont would not accept the potential offer for independence. Delegates had little idea why this rejection would have taken place, and Connecticut delegates wrote that "It Appears Very strange

\footnotetext{
200 Samuel Livermore to Meshech Weare, August 7, 1781, LDC 17: 479.

${ }^{201}$ Samuel Livermore to Meshech Weare, August 14, 1781, LDC 17: 511.

202 Committee of Congress Interview with the Vermont Agents, August 18, 1781, LDC 17: 528-30.

${ }^{203}$ Ezra L'Hommedieu to George Clinton, August 21, 1781, LDC 17: 548.

204 Ezra L'Hommedieu to George Clinton, September 8, 1781, LDC 18: 23.
} 
that this People will not now Accept of what they have for a long Time been endeavouring."205 Vermont's leaders had decided that conceding to the congressional suggestion would reduce their leverage in the situation and refused to begin any other discussion until given entry into the confederation. ${ }^{206}$ The rejection was a setback for congressional favor toward Vermont independence; however, it began the final stages of the debate in Congress over the issue. As Livermore wrote, "Congress are much divided and cannot agree to any one thing." 207 Options as diverse as military action and further reconciliation were on the table, but no agreement could be found, as the controversy had reached uncharted territory of congressional involvement. ${ }^{208}$ New York delegates were taken aback by the situation and could not understand how Vermont kept some friends in Congress despite the fact that "their Conduct was Directly against the United States and in favor of our Enemies." 209 The fact that Vermont considered working with England was shocking to New York. On the other hand, New Hampshire delegates pondered the idea of an even split of Vermont between themselves and New York, but did not know whether Congress could agree to any action at all.210 "Some members of Congress are much alarmed \& all are embarrassed at the present situation of Vermont," wrote Livermore, "but they have such repugnant ideas \& interests or rather Attachments, as render it very difficult, if not impossible, to bring them to agree to any one thing." 211 It was clear from letters that delegates were unhappy with the situation that existed after Vermont's January 1782 rejection. New England delegates

205 Connecticut Delegates to Jonathan Trumbull, Sr., January 21, 1782, LDC 18: 293-94.

206 Taplin, 241-42.

207 Samuel Livermore to Meshech Weare, January 21, 1782, LDC 18: 295.

208 James Madison to Edmund Pendelton, January 22, 1782, LDC 18: 297-98.

209 William Floyd to George Clinton, February 5, 1782, LDC 18: 325.

210 Samuel Livermore to Meshech Weare, February 11, 1782, LDC 18: 330.

211 Samuel Livermore to Meshech Weare, February 5, 1782, LDC 18: 326. 
made an attempt to vote for independence, but only six states voted in favor. ${ }^{212}$ Congress was divided on the best course of action, and the Vermont controversy had once again proven too difficult, if not impossible, to solve for Congress. As usual, Congress pushed a final decision to a later date.

\section{"A Theme fruitful of Reflection": Institutional Thought}

The context of war against Great Britain and the struggle for power between the new states weighed most heavily on the delegates' minds during the Vermont controversy, but a select few-especially the delegates farthest from the conflict—sought the consideration of the broader institutional implications of congressional action in the dispute. The bulk of the interest in the Vermont dispute from less-involved delegates came during moments of crisis, evident especially in the 1781 resolves. Those conversations revolved mostly around the war effort, not congressional power. Although it had been going on in the background for the duration of the controversy, Vermont's rejection of Congress's offer for independence brought other delegates into the discussion over the institutional implications of settlement. In the vote for independence of March 1782, numerous states voted against Vermont "on supposition of the want of authority in Congress so to declare them." 213 The difference of opinion which arose from the rejection divided Congress over the best course of action. "In this delicate crisis the interposition of Congress is again called for, \& indeed seems to be indispensable; but whether in the way of military coercion, or a renewal of former overtures, or by making the first a condition of the last, is not so unanimously decided," wrote Madison of a Congress concerned over setting a bad

212 South Carolina Delegates to John Rutledge, March 4, 1782, LDC 18: 372. 213 New York Delegates to George Clinton, March 5, 1782, LDC 18: 376-78. 
precedent. ${ }^{214}$ Given his view of Congress at a standstill, Madison summarized the deeper, institutional conflict: "Nothing is more distressing to those who have a due respect for the constitutional modifications of power than to be obliged to decide on them." 215

New York and New Hampshire delegates brought up the same concerns over the right of Congress to decide in favor of Vermont and rejecting the residents of Vermont claiming the ability to separate from existing states. However, their rhetoric was tied to their overall interests in property claims and a desire for independence in the disputed territory. These thoughts existed before 1782, and North Carolina delegate Thomas Burke was one of the first to express concern over the controversy in Congress. Writing to North Carolina Governor Richard Caswell in 1777 about the introduction of the controversy, he hoped that Congress "will be wise enough to decline any interposition. I am for my own part clearly against assuming a Judiciary power."216 His wish came true until the 1781 offer of independence when Congress decided to make a final decision.

The institutional development of the Articles of Confederation provided the roots of the political debate over the Vermont controversy. The states ratified the Articles and they took effect in March 1781 before the bulk of congressional debate on Vermont. Specifically, Article IX of the Articles contained sections relevant to the debate before Congress. "The united states in congress assembled shall also be the last resort in appeal in all disputes and and differences now subsisting or that hereafter may arise between two or more states concerning boundary, jurisdiction or any other cause whatever," read the article, followed by a procedure for

214 James Madison to Edmund Pendleton, January 22, 1782, LDC 18: 297-98.

215 Ibid., 298.

216 Thomas Burke to Richard Caswell, April 29, 1777, LDC 6: 671-672. 
adjudication of these matters. ${ }^{217}$ Delegates agreed that the Articles governed the situation; however, the dispute over Vermont did not fit squarely into one interpretation of the Articles. Certainly territory and boundary issues existed between the recognized states New York, New Hampshire, and (depending on their mood) Massachusetts. Conflicting land grants were also at stake in the controversy. However, the non-sanctioned Vermont also claimed both territory and grants of land; so, accepting the reality of the situation, Congress had to be careful to include them without explicit recognition. In a later debate over how to react to an action by Vermont, Madison acknowledged that bringing their leaders in for a trial would "be a stronger recognition go its independence than Congress had made or meant to make." ${ }^{218}$ Placed in this situation, the context forced Congress to define the limits of its power to define states.

A leader in bringing about the institutional questions early on, Madison espoused a framework for Article IX of the yet-to-be-ratified Articles in 1780, according to Duane's notes. In debate, he stated that "if the District in Question was comprehended within the Jurisdiction of one or more of the United States, it must necessarily follow, that the Inhabitants could have no Right to set up an independent State ... it had been clearly proved to lie within New York or New Hampshire: for as these States were bounded upon each other there could be no Room

217 "The Articles of Confederation," in Documents of American History, Seventh Edition, ed. Henry Steele Commager (New York: Appleton-Century-Crofts, 1963), 113-114. Article IX went further still: "All controversies concerning the private right of soil claimed under different grants of two or more states, whose jurisdictions as they may respect such lands, and the states which passed such grants are adjusted, the said grants or either of them being at the same time claimed to have originated antecedent to such settlement of jurisdiction, shall on petition of either party to the congress of the united states, be finally determined as near as may be in the same manner as is before prescribed for deciding disputes respecting territorial jurisdiction between different states."

218 James Madison's Notes of Debates, November 27, 1782, LDC, 19:427-28. 
between them for another Jurisdiction." 219 Yet, was Vermont's situation unique enough to be exempt from the strict guidelines laid down by Madison? Georgia delegate Richard Howly said yes, arguing that Vermont had existed as a unit—opposed to New York rule—-before the dispute reached Congress. He said that "the King of Great Britain had no power without their own Consent to annex them to New York. .. they had a Right to become Independent on the same principles which had Authorized these States to shake off the British Yoke."220 Comparisons of New York to Britain were bold and uncommon; yet, some delegates did make similar statements to show support for Vermont and oppose the strict reading of Article IX.

Soon after Congress attempted to allow Vermont independence in 1781, New Jersey delegate Elias Boudinot wrote of Vermont's argument for independent existence before the revolution. Crediting popular sovereignty, he quoted the Vermont agents as saying that "at the Revolution they were in a State of Nature-That they then set up a new Government and have ever since been in the actual Possession of Sovereign Power."221 This argument was not without pitfalls, as Boudinot himself pointed out the next year. He raised an important question: "Can Congress as sovereign Guardians of the United States, when they conceive the general Safety of the common Cause shall require it, recieve into the Union as a separate State, any Territory \& People in the actual Possession of Sovereignty \& Independence de facto, without examining into \& determining the Right \& Title of such People de Jure?"222 A South Carolina delegate

219 James Duane's Notes on Debates, October 6, 1780, LDC, 16:150-151.

220 Ibid. 16:150-151. This language was strikingly similar to the rhetoric cited by historians such as Bailyn or Wood in their respective studies of the ideological underpinnings of the American Revolution. It was especially notable coming from a Southern delegate, as they tended to oppose the addition of more Northern states due to the potential to disrupt regional balance in Congress.

${ }^{221}$ Elias Boudinot to William Livingston, August 25, 1781, LDC 17:559.

222 Elias Boudinot to William Livingston, October 23, 1782, LDC 19:297. 
preoccupied with the institutional implications of the Vermont issue, Arthur Middleton, said that it could not look only to de facto sovereignty or decide to create new states from within current states at all "because it will be a precedent for future Divisions of the larger States-but above all because Congress have no power to grant such admission, \& the only ground hitherto pleaded for the measure has been of policy \& not of Right." ${ }^{223}$ Delegates would vacillate on the questions of de facto sovereignty and state admission throughout the rest of the Congress. While political interests played a key role in that debate, these questions solidified the divide between the ardent supporters of each side. The first instance of this debate came upon the surprising news that Vermont withdrew their rejection of the 1781 resolves.

"Admitting so many Serpents": A Second Consideration

According to a March 1782 letter from New Hampshire delegate Samuel Livermore, a rumor that Vermont had changed their minds and agreed to follow the 1781 resolutions arose in Congress. ${ }^{224}$ Hoping that the "hurly burly" was done, Livermore was privately willing "to give them independence, \& receive them into confederation, if that would end our troubles upon the subject," yet the vote was seven in favor and five opposed, not enough to gain approval. ${ }^{225} \mathrm{New}$ York delegates saw this reconsideration in the exact opposite light, again questioning the Vermonter's loyalty to the United States. "Whereas every disinterested person must clearly see that by establishing the Independence of the Grants \& admitting them into the Union, the Influence of their wicked Leaders will be rendered permanent, and endanger the Safety of these

${ }^{223}$ Arthur Middleton's Memorandum on a Vermont Report, January 28, 1782, LDC 18:306-7. ${ }^{224}$ Samuel Livermore to Meshech Weare, March 12, 1782, LDC, 18: 389. In fact, Vermont had passed resolutions agreeing to follow the congressional resolutions.

225 Ibid., 389. 
united States, by admitting so many Serpents into our Bosom to poison our Councils, divulge our Secrets and give an easy Admission to the Enemy into the Heart of the American Empire," they wrote to Clinton, adding that "nothing but their Inability to increase their Number to nine States, can prevent the Execution of the dangerous plan \& arbitrary dismemberment of our unhappy State."226 That a second chance for Vermont might be considered brought New York's leaders to the height of their frustrations, and all forces that worked against them recommended delay on the issue.

In an effort to undermine a new committee made up entirely of Vermont supporters, New York delegate John Morin Scott sought to enter Governor Chittenden's initial rejection of the 1781 resolutions into the record. This action would have bolstered their argument that the 1781 independence offer was void. However, this effort failed and Scott wrote that it was "evidently the fixed and settled purpose of the Majority to sacrifice its Rights on the Alter of the Independence of Vermont." ${ }^{227}$ In addition, southern states remained concerned about the future of the confederacy if a regional balance was thrown off. In April 1782, Arthur Lee of Virginia wrote to Samuel Adams of his feeling that "with the admission of this little State the confederation will end; its present inequality being as much as it can bear."228 The reason delay was possible had little to do with support for Vermont's cause, however. In addition to the land promises allegedly made by Vermont to supportive delegates, ${ }^{229}$ the larger debate over western lands forced itself into the Vermont controversy. "The true secret is that the Vote of Vermont is

${ }^{226}$ New York Delegates to George Clinton, March 12, 1782, LDC 18: 392.

227 John Morin Scott to George Clinton, April 2, 1782, LDC 18: 435-36.

${ }^{228}$ Arthur Lee to Samuel Adams, April 21, 1782, LDC 18: 462-63.

229 New York Delegates to George Clinton, March 29, 1782, LDC 18: 427-28. 
wished for as an auxiliary agt. the Western claims of Virga. . . Some of the E. States which are anxious for the admission of Vermont see this and impede the adjustment of Western boundaries on the ground of the Cessions," wrote Madison. ${ }^{230}$ According to Madison, Pennsylvania only supported Vermont because of the western lands issue; if this issue was resolved, Vermont would be denied independence. ${ }^{231}$ In the fall of 1782 Vermont once again precipitated a situation in which Congress was forced to act against them.

"A fair way to ruin themselves": Controversy in Cumberland County

In September 1782, a dispute between the competing civil governments of Vermont and New York in Cumberland County led to a small-scale military operation led by Ethan Allen, which, in turn, resulted in swift action by George Clinton and his delegates in Congress. ${ }^{232}$ "This New and unexpected Violence ... will we trust induce Congress immediately to interpose and exert their Authority for the Releif, and Protection of those unhappy People, our Fellow Citizens, now made Prisoners by a lawless Power," wrote the delegates to Clinton, promising to get Congress to enforce the 1779 resolutions. ${ }^{233}$ A recommendation on the issue was delayed by the committee, concerning New York delegates. ${ }^{234}$ According to Samuel Osgood of Massachusetts, the New Yorkers pressed for a decision, but a victory for either side was unlikely. ${ }^{235}$ One of Vermont's few allies, Rhode Island tried legislative maneuvering, but their efforts to confirm independence under the 1781 resolution failed to achieve the necessary seven votes. ${ }^{236}$ The

230 James Madison to Edmund Pendleton, April 23, 1782, LDC 18: 467.

231 James Madison's Observations, May 1, 1782, LDC 18: 481-82.

232 Taplin, 263-64.

${ }^{233}$ New York Delegates to George Clinton, September 21, 1782, LDC 19: 195.

234 Ezra L'Hommedieu to George Clinton, October 16, 1782, LDC 19: 270.

235 Samuel Osgood to John Lovell, October 23, 1782, LDC 19: 305-06.

236 David Howell to Nicholas Brown, November 5, 1782, LDC 19: 342. 
combination of the Cumberland County violence and a New York compromise on western lands made Vermont independence look as unlikely as it ever had. Madison wrote that "Duane seems not unapprized of the advantage which New York has gained and is already takeing measures for a speedy vote on that question ... she has acquired with Congress the merit of liberality rendered the title to her reservation more respectable and at least dampt the zeal with which Vermont has been abetted." ${ }^{237}$ According to Rhode Island delegate David Howell, Vermont independence was met "with every opposition you can imagine."238

In November, the committee made its report on the Cumberland County situation. However, it proved weak, confirming the New York delegation's worst concerns about action in favor of New York. ${ }^{239}$ New York still faced serious opposition within Congress, as delegates believed the New York delegates created the Cumberland County issue when they decided to send commissioners into an area the Vermont government sought to control.240 To New York, these statements "served to shew a clear alteration of Sentiment, with respect to Vermont ..." and led delegates to believe no action would come from Congress. ${ }^{241}$ Even a report of spying in Vermont had few results, as many thought having a trial for its leaders would "be a stronger recognition of its independence than Congress had made or meant to make.”242 Eventually, Congress passed resolutions condemning Vermont's actions in Cumberland County, but delegates entertained no hope that they would be enforced, writing that the only benefit to them was that

${ }^{237}$ James Madison to Edmund Randolph, November 5, 1782, LDC 19: 349. This message was written with cipher, and markings were removed in order to improve readability.

${ }^{238}$ David Howell to Moses Brown, November 6, 1782, LDC 19: 357.

${ }^{239}$ Ezra L'Hommedieu to George Clinton, November 13, 1782, LDC 19: 379.

240 Samuel Osgood to John Lowell, November 14, 1782, LDC 19: 383-88.

${ }^{241}$ James Duane to George Clinton, November 15, 1782, LDC 19: 390.

242 James Madison's Notes of Debates, November 27, 1782, LDC 19: 427-28. 
they gave "a complexion to the future deliberations on the subject and may induce Congress the more readily to adopt some moderate medium." 243 These resolutions constituted the beginning of the anti-climactic ending of the Vermont controversy in Congress.

“A body so mutable”: Indecision in Congress

During the Revolutionary War, delegates often stated that they would have more time for issues such as the Vermont controversy once the business of war was over. Yet, once the war ended in 1781, they turned their attention to the business of nation-building, and the Vermont controversy earned even less attention. Added into the mix was nationalist-minded Alexander Hamilton, who was the new delegate for New York. "I have little hope that we shall ever be able to engage Congress to act with decision upon the matter or that our State will ever recover any part of the revolted territory but upon a plan that will interest the two States I have mentioned, or at least one of them," he wrote to Clinton. ${ }^{244}$ A plan to work with New Hampshire garnered some attention, but he wrote that "It is a business in which nobody cares to act with decision."245 The final act of the controversy was not without some drama, however, as Chittenden responded to the recent Cumberland County resolutions with an angry 22-page letter railing against congressional interference in the internal affairs of Vermont. ${ }^{246}$ New Hampshire delegate Phillips White noted that Chittenden no longer had any qualms with open dispute with the United States even though he still wanted to remain a part of it. ${ }^{247}$ Reflecting the mood of the

243 December 5, 1782, JCC 23: 765-69; New York Delegates to George Clinton, December 9, 1782, LDC 19: 469.

${ }^{244}$ Alexander Hamilton to George Clinton, January 1, 1783, LDC 19: 527.

245 Alexander Hamilton to George Clinton, January 12, 1783, LDC 19L 578.

246 James Madison's Notes of Debates, February 4, 1783, LDC 19: 653-55.

247 Phillips White to Josiah Bartlett, February 5, 1783, LDC 19: 662. 
Congress has a whole, he wondered aloud whether the committee appointed to respond to the letter "may procure some new resolution that will never be Carried into execution."248

New York delegates did make one last ditch effort to claim Vermont, but never acted upon the threat. In 1784, the New York legislature issued a statement to Congress which contained a threat to solve the problem by itself - through arms - if Congress would not take action. "If the decision which has so long, in vain been solicited, should not be pronounced within two Months ... the said State of New York with whatever deep regret will be compelled to consider herself as left to pursue her own Council, destitute of the protection of the United States, to whose judgement they have cheerfully submitted, and on whose justice they have hitherto relied," they wrote. ${ }^{249}$ The talk was certainly tough; New York delegate Ephraim Paine suggested that the state should take "the Same measures as though it was Surrounded with open and avowed Enemies."250 Some delegates believed the claims, with Richard Debbs Spaight of North Carolina predicted that "the flames of civil war will be kindled in that Country in the course of four or five months." ${ }^{251}$ This prediction was incorrect, and while the same arguments were raised, New York never acted upon their threat or brought up their claim. ${ }^{252}$

The combination of New York's lack of follow-through and the continued lack of congressional interest in the Vermont controversy led the issue to wind down until the start of the 1787 Constitution in 1789. During that period, American statesmen recognized the weaknesses of the Articles of Confederation and turned their attentions to issues much more complicated than

248 Phillips White to Meshech Weare, March 5, 1783, LDC 19: 771.

${ }^{249}$ New York Delegates to Congress, April 24, 1784, LDC 21: 539-543.

250 Ephraim Paine to George Clinton, April 30, 1784, LDC 21: 557.

251 Richard Debbs Spaight to Alexander Martin, April 30 1784, LDC 21: 567.

252 William Samuel Johnson to Roger Sherman, April 20, 1785, LDC 22: 349. 
war: nation building. Hamilton himself used the issue to expose inherent weaknesses in the Confederation Congress. "It is hazardous to pass a positive judgement on what will happen in a body so mutable as that of Congress ... While Congress have a discretion they will procrastinate; when they are bound by the constitution they must proceed."253 For ten years or more, Congress procrastinated on the issue of Vermont. But throughout that process, they debated the powers and limits of Congress.

"May 'ere long be admitted": The Fourteenth State

Vermont did not follow the normal path to statehood for that time period as the Northwest Ordinance of 1787 would come to constitute the main process for entering the Union. Onuf, in his 1987 Statehood and Union: A History of the Northwest Ordinance, described the law as "one of the most important documents of the American founding period ... Drafted at a time of sectional division and constitutional crisis, it also embodies a vision of a more harmonious, powerful, prosperous, and expanding union." 254 Vermont's entry into the Union was not influenced by the Northwest Ordinance; its controversy influenced the development of the Northwest Ordinance. Onuf wrote that Vermont demonstrated how "frontiersman were capable of forming their own new states," so Congress felt the need to anticipate similar disputes in the future. ${ }^{255}$

Vermont's situation was much more similar to that of Kentucky, the fifteenth state, who also sought to split from a larger state. In Kentucky's case, that larger state was Virginia. As

253 Alexander Hamilton to George Clinton, July 27, 1783, LDC 20: 467-68.

${ }^{254}$ Peter S. Onuf, Statehood and Union: a History of the Northwest Ordinance (Bloomington, IN: Indiana University Press, 1987), xiii.

255 Onuf, Statehood and Union, xix. 
early as 1776 , Kentuckians petitioned to Congress to request recognition as a separate colony, much like Vermont. 256 They were also similar in that they were well-established settlements, without as much need for the procedure outlined by the Northwest Ordinance. ${ }^{257}$ The Kentucky situation in western Virginia was ultimately beneficial to Vermonters, as it offered a regional balance in the admission of both states to the Union, assuaging concerns of skeptical Southern delegates. Massachusetts delegate Samuel A. Otis acknowledged the awkward nature of transition felt by both Vermont and Kentucky, writing that each state government was made to wait during the ratification period until the new government, under the 1789 Constitution, could approve them. ${ }^{258}$ The two states were alike in the unique questions they presented to Congress.

During the lead-up to the 1787 Constitutional Convention, it was all but certain to delegates that Vermont would be the fourteenth state. A big step occurred in March 1787 when Alexander Hamilton made a motion in the New York legislature to recognize Vermont as an independent state. ${ }^{259}$ The state that was the biggest—and often the only—obstacle to Vermont statehood had now stepped aside, paving the way for statehood. The question remained as to whether Vermont would enter the confederacy or wait until the 1787 Constitution took effect. Nathan Gilman noted that "the people in Vermont are federally inclined and much in favor of the new Constitution, ${ }^{260}$ and Vermonters assured Hamilton that they would not ask for any

256 George Morgan Chinn, Kentucky: Settlement and Statehood 1750-1800 (Frankfort, KY: Kentucky Historical Scoeity, 1975), 212. This monograph offered a detailed summary of Kentucky's quest for statehood. See also Benjamin M. Gies "Kentucky's First Statesman: George Nicholas and the founding of the Commonwealth," (MA thesis, University of Louisville, 2015).

${ }^{257}$ Onuf, Statehood and Union, 54.

${ }^{258}$ Samuel A. Otis to John Adams, July y, 1788, LDC 25: 213.

${ }^{259}$ Nathan Dane to Thomas Dwight, March 12, 1787, LDC 24: 141.

260 Nicholas Gilman to John Langdon, June 5, 1788, LDC 25: 213. 
amendments while ratifying. ${ }^{261}$ Ultimately, it required a new nation and a loss of interest from New York for the issue to be resolved as the Continental Congress proved unable to resolve the situation on their own. While delegates were frustrated at the time, the impact the controversy had on American institutions of government was much more far-reaching. It helped teach the Founders the limits of the Articles of Confederation and showed them the need for the structure offered by the 1787 Constitution.

\section{Conclusion: A Vision for a Federal System}

The Continental Congress's failure to resolve the Vermont controversy created more questions about American constitutional government than it answered. While frustrating to many delegates to Congress, this circumstance reflected so much of the general struggle to create a new nation. Unprecedented situations faced delegates to Congress in most of their work, and while they related their values and ideals to the traditions of American government and colonial experience, nation-building was a complicated art. For the most part, delegates involved in the controversy focused on personal land interests and old rivalries between the colonies. Yet, as Bernstein noted, old rivalries revealed the weaknesses of the confederation. ${ }^{262}$ Onuf wrote that "many Americans came to believe that only a vigorous national government could prevent the disintegration of the states themselves."263 For this reason, some delegates thought beyond short-term concerns and viewed the long-term consequences of the debate.

261 Alexander Hamilton to Nathaniel Chipman, September 1788, LDC 24: 397.

262 Bernstein, 86.

263 Onuf, The Origins of the Federal Republic, 149. 
Two key players in the Vermont controversy-Alexander Hamilton and James Madison —offered their own vision for the United States of America in the Federalist Papers, and in doing so elaborated upon the principles underlying the controversy. In the new government formed by the 1787 Constitution, they sought to correct the flaws in the Articles of Confederation; flaws they observed firsthand throughout the Vermont controversy. The prospect of civil war concerned Hamilton, a threat that was brought up in Congress as a potential result of Vermont independence. "To look for a continuation of harmony between a number of independent unconnected sovereignties, situated in the same neighbourhood," he wrote, "would be to disregard the uniform course of human events, and to set at defiance the accumulated experience of ages." 264 This realist view led him to believe that "the jealousy of power, or the desire of equality and safety" which existed among states meant that only republican institutions could survive. ${ }^{265}$ He identified territorial disputes as the leading cause of war between peoples using Vermont as the example of its possibility in the United States. ${ }^{266}$ Unlike other New York Delegates in the Vermont controversy, who were more focused upon their own economic interests and pride for their state, Hamilton feared its implications upon a federal system. "In a review of these transactions," he wrote, "we may trace some of the causes which would be likely to embroil the states with each other."267 In Hamilton's view, jealousy and distrust would always exist among people, but only a document like the Constitution provided the mechanism to overcome them. Article IX of the Articles of Confederation, designed to settle these disputes

\footnotetext{
${ }^{264}$ Alexander Hamilton, Federalist 6, 21.

265 Hamilton, Federalist 6, 21-23.

266 Hamilton, Federalist 7, 26-28.

${ }^{267}$ Hamilton, Federalist 7, 28.
} 
between states, was never enough to settle such disputes. In Federalist 28, he wrote that "if ... insurrection should pervade a whole state, or a principal part of it, the employment of . . f force might become unavoidable, ${ }^{268}$ arguing that a national government with the power to peaceably settle a dispute was an absolute necessity for national security.

The Vermont controversy involved a tension between a revolution-minded people and an elite party, between ideologically diverse individual, and between delegates who disagreed upon the true powers of their institution. Madison saw these same points of disagreement in the United States as a whole. However, the combination of a stable constitutional structure and diverse ideologies allowed the United States to be more successful. As Madison argued, "the different governments [state and federal] will control each other; at the same time that each will be controled by itself ... The society itself will be broken into so many parts, interests, and classes of citizens that the rights of individuals, or the minority, will be in little danger from interested combinations of the majority." ${ }^{269}$ People and power could balance one another out if given the proper structure. The Vermont controversy illustrated the value of limited government in a state-based federal system to Madison, Hamilton, and other Founders.

Reflecting the values of Hamilton and Madison, Onuf's later work identified the solution called for in the Vermont controversy. The national government required a consistent system to handle this and other similar jurisdictional controversies, but Congress was unwilling to give themselves this power whether by adding to the Articles or by legislating it to themselves. $\mathrm{He}$ wrote that "one of the hallmarks of American constitutional development, reflecting the crisis of

${ }^{268}$ Hamilton, Federalist 28, 136.

269 Madison, Federalist 51, 270. 
legitimacy in new state governments, was to identify legitimate, constituent authority ..."270 While certain delegates sought resolution, no one sought to achieve this government stability in Vermont. After numerous decades and little congressional action, no action ever took place. The Vermont controversy tested the new federal balance between the states and the federal government.

270 Onuf, "State Making,” 813. 


\section{Bibliography:}

\section{Primary Sources}

Carey, George W. and McClellan, James, eds. The Federalist Papers: Gideon Edition. Indianapolis, IN: Liberty Fund, Inc., 2012.

Chittenden, Thomas. The Public Papers of Governor Thomas Chittenden. Edited by John A. Williams. Montpelier, VT: Vermont Secretary of State, 1969.

Clinton, George. Public Papers of George Clinton, First Governor of New York, 1777-1795, 1801-1804. 10 vols. Edited by James A. Holden and Hugh Hastings. New York: State of New York: 1899-1914.

Commager, Henry Steele, ed. Documents of American History, Seventh Edition. New York: Appleton-Century-Crofts, 1963.

Smith, Paul H., et al., eds. Letters of Delegates to Congress, 1774-1789. 25 vols. Washington, D.C.: Library of Congress, 1976-2000.

Ford, Worthington C., et al., eds. Journals of the Continental Congress. 34 vols. Washington, D.C.: Library of Congress, 1904-1937.

Weare, Meshech, Papers. Massachusetts Historical Society, Boston, MA.

Secondary Sources

Alexander, Edward P. A Revolutionary Conservative: James Duane of New York. New York: Columbia University Press, 1938.

Bailyn, Bernard. The Ideological Origins of the American Revolution. Cambridge, MA: Harvard University Press, 1967.

Beard, Charles A. An Economic Interpretation of the Constitution of the United States. New York: The Macmillan Company, 1913.

Bernstein, Richard B. and Kym S. Rice. Are We to Be a Nation? The Making of the Constitution. Cambridge, MA: Harvard University Press, 1987.

Bilder, Mary Sarah. Madison's Hand: Revising the Constitutional Convention. Cambridge, MA: Harvard University Press, 2015.

Burnett, Edmund C. The Continental Congress. New York: The Macmillan Company, 1941. 
China, George Morgan. Kentucky: Settlement and Statehood 1750-1800. Frankfort, KY: The Kentucky Historical Society, 1975.

Coleman, Aaron N. The American Revolution, State Sovereignty, and the American Constitutional Settlement, 1765-1800. Lanham, MD: Lexington Books, 2016.

Davis, Derek H. Religion and the Continental Congress, 1774-1789: Contributions to Original Intent. Oxford: Oxford University Press. 2000.

Hall, Hiland. The History of Vermont from Its Discovery to Its Admission into the Union in 1791. Albany, NY: J. Munsell, 1868.

Jensen, Merrill. The Articles of Confederation: An Interpretation of the Social-Constitutional History of the American Revolution, 1774-1781. Madison, WI: University of Wisconsin Press, 1940.

-. The New Nation: A History of the United States During the Confederation, 1781-1789. New York: Alfred A. Knopf, 1950.

Jones, Matt Bushnell. Vermont in the Making: 1750-1777. Cambridge, MA: Harvard University Press, 1939.

Kaminski, John P. George Clinton: Yeoman Politician of the New Republic. Madison, WI: Madison House, 1993.

Kurtz, Stephen G. and Hutson, James H., eds. Essays on the American Revolution. Chapel Hill, NC: University of North Carolina Press, 1973.

Maier, Pauline. American Scripture, Making the Declaration of Independence. New York: Vintage Books, 1997.

McDonald, Forrest. We the People: The Economic Origins of the Constitution. Chicago, IL: University of Chicago Press, 1958.

-. E Pluribus Unum: The Formation of the American Republic, 1776-1790. Indianapolis, IN: Liberty Press, 1979.

-. Novus Ordo Seclorum: The Intellectual Origins of the Constitution. Lawrence, KS: University Press of Kansas, 1985.

Onuf, Peter S. The Origins of the Federal Republic: Jurisdictional Controversies in the United States, 1775-1787. Philadelphia: University of Pennsylvania Press, 1983. 
Statehood and Union: A History of the Northwest Ordinance. Bloomington, IN: Indiana University Press, 1987.

Rakove, Jack N. The Beginnings of National Politics: An Interpretive History of the Continental Congress. New York: Alfred A. Knopf, 1979.

-. Original Meanings: Politics and Ideas in the Making of the Constitution. New York: Alfred A. Knopf, 1996.

Taplin, Winn L. Jr., "The Vermont Problem in the Continental Congress and in Interstate Relations, 1776-1787.” PhD Diss., University of Michigan, 1955.

Williamson, Chilton. Vermont in Quandary: 1763-1825. Montpelier, VT: Vermont Historical Society, 1949.

Wood, Gordon S. The Creation of the American Republic, 1776-1789. Chapel Hill, NC: University of North Carolina Press, 1969. 1992.

\section{Scholarly Articles}

Graffagnino, J. Kevin, “"The Country My Should Delighted in': The Onion River Land Company and the Vermont Frontier." The New England Quarterly, 65 (Winter 1992): 24-60.

Greene, Jack P. "The Background of the Articles of Confederation." Publius 12, 4 (1982): 15-44.

Morris, Richard B. "The Forging of the Union Reconsidered: A Historical Refutation of State Sovereignty over Seabeds.” Columbia Law Review 74, 6 (1974): 1056-1093.

Onuf, Peter S. "State-Making in Revolutionary America: Independent Vermont as a Case Study." The Journal of American History 67 (March 1981): 797-815. 


\section{$\underline{\text { Appendix I: Timeline }}$}

1750: New Hampshire colonial Governor Bennington Wentworth began to make grants in the territory that would become Vermont. It was known as the New Hampshire Grants.

1764: The British Privy Council declared the boundary of New York "to be" the Connecticut River. It served to exacerbate the dispute.

May 8, 1776: New Hampshire Grants residents presented a petition to committee of Congress.

May 10, 1776: Continental Congress issued resolution advising states to form their own governments, encouraging residents of the New Hampshire Grants.

July 4, 1776: National Declaration of Independence approved; residents of the New Hampshire Grants began to turn away from Britain as a source of power.

January 15, 1777: Vermont declares independence as the state of New Connecticut at a convention in Westminster, Vermont.

June 11, 1778: Vermont legislature granted approval to the action of western New Hampshire towns, who sought to unite the Connecticut River Valley. This brought New Hampshire into the debate on the side of New York.

September 24, 1779: Congress passed resolutions urging involved states to give Congress jurisdiction to settle dispute. It also forbade continued land grants. A lack of quorum delayed hearings on the matter.

March 1781: States ratified the Articles of Confederation.

July 10, 1781: George Washington received intelligence revealing British overtures to Vermont leaders. This information created a sense of urgency in Congress.

August 7, 1781: Congress appointed a committee to work out terms of independence and statehood with Vermont.

January 21, 1782: Delegates discovered that Vermont rejected the offer for independence. Vermont Gov. Thomas Chittenden confirmed this development in a letter to Congress.

March 12, 1782: Vermont legislature passed resolutions to meet with committee to offer independence.

September 21, 1782: New York officials in Cumberland County apprehended, led to crisis in New York over Vermont. 
December 5, 1782: Congress passed resolution rejecting Vermont actions in Cumberland County, no further action came from this resolution.

April 24, 1784: In a latter to Congress, New York Delegates threaten to take matter into their own hands if Congress did not decide within two months. No further action came from this letter.

September 17, 1787: United States Constitution ratified.

March 4, 1789: First Congress met in New York City.

March 4, 1791: Vermont became the fourteenth state in the Union. 


\section{Appendix II: Map of Vermont and Surrounding Area}

Reprinted from Winn L. Taplin Jr., "The Vermont Problem in the Continental Congress and in Interstate Relations, 1776 - 1787,’” (PhD diss., University of Michigan, 1955).

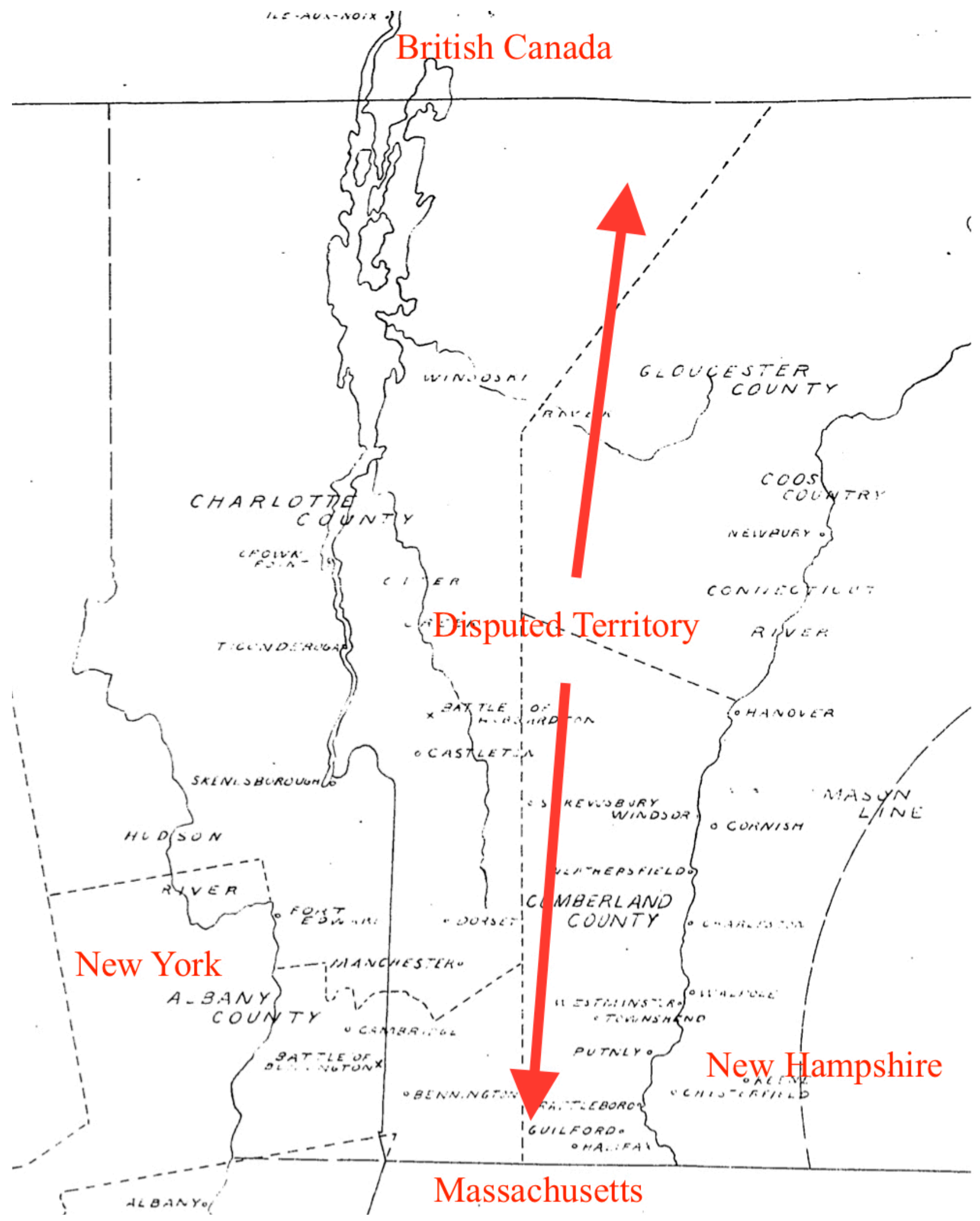

